\title{
The neurovascular unit in leukodystrophies: towards solving the puzzle
}

\author{
Parand Zarekiani ${ }^{1,2,3 \dagger}$, Henrique Nogueira Pinto ${ }^{3,4 \dagger}$, Elly M. Hol ${ }^{4}$, Marianna Bugiani ${ }^{1,2 \dagger}$ and Helga E. de Vries ${ }^{3{ }^{*}+}$
}

\begin{abstract}
The neurovascular unit (NVU) is a highly organized multicellular system localized in the brain, formed by neuronal, glial (astrocytes, oligodendrocytes, and microglia) and vascular (endothelial cells and pericytes) cells. The bloodbrain barrier, a complex and dynamic endothelial cell barrier in the brain microvasculature that separates the blood from the brain parenchyma, is a component of the NVU. In a variety of neurological disorders, including Alzheimer's disease, multiple sclerosis, and stroke, dysfunctions of the NVU occurs. There is, however, a lack of knowledge regarding the NVU function in leukodystrophies, which are rare monogenic disorders that primarily affect the white matter. Since leukodystrophies are rare diseases, human brain tissue availability is scarce and representative animal models that significantly recapitulate the disease are difficult to develop. The introduction of human induced pluripotent stem cells (hiPSC) now makes it possible to surpass these limitations while maintaining the ability to work in a biologically relevant human context and safeguarding the genetic background of the patient. This review aims to provide further insights into the NVU functioning in leukodystrophies, with a special focus on iPSC-derived models that can be used to dissect neurovascular pathophysiology in these diseases.
\end{abstract}

Keyword: Neurovascular unit, Blood-brain barrier, Leukodystrophies, In vitro models, Induced pluripotent stem cells, Endothelium, Astrocyte, Pericyte, Microglia

\section{Background}

The neurovascular unit (NVU) is a complex dynamic structure present in the microvasculature of the central nervous system (CNS). It is comprised of brain endothelial cells (BECs), pericytes, astrocytes, microglia, and neurons. Its proper function is key for the maintenance of brain homeostasis by separating the blood from the CNS [1]. Also, the NVU is responsible for neurovascular coupling (NVC), which is the mechanism that adjusts local blood supply to neuronal demand through changes in vascular intraluminal diameter [1].

\footnotetext{
*Correspondence: he.devries@amsterdamumc.nl

${ }^{\dagger}$ Parand Zarekiani and Henrique Nogueira Pinto shared first authors

${ }^{\dagger}$ Marianna Bugiani and Helga E. de Vries shared last authors

${ }^{3}$ Department of Molecular Cell Biology and Immunology, Amsterdam

Neuroscience, Amsterdam UMC, Vrije Universiteit Amsterdam, De Boelelaan 1117, Amsterdam, The Netherlands

Full list of author information is available at the end of the article
}

At the capillaries, the first line of defence is a layer of specialized polarized BECs, which are sealed together by protein complexes that form adherens junctions (AJs) comprised of VE-Cadherin, and tight junctions (TJs), formed by claudins, occludin and other cytoplasmic plaque proteins. This endothelial structure is referred to as the blood-brain barrier (BBB). BECs lack fenestrae and have low rates of transcytosis, thereby disabling transcellular and paracellular routing of molecules into the CNS. Metabolites, nutrients, and (large) essential molecules are actively transported across the BECs into the CNS by specific polarized transporters. In turn, toxins, xenobiotics, and waste products are actively removed from the CNS by another class of polarized transporters, i.e. ATP binding cassette $(\mathrm{ABC})$ transporters. Additionally, $\mathrm{BECs}$ physical barrier properties regulate infiltration of peripheral immune cells into the CNS to modulate the adaptive neuroinflammatory response [2-9].

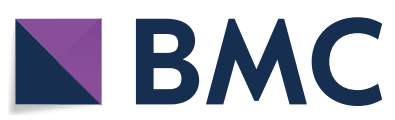

(c) The Author(s) 2022. Open Access This article is licensed under a Creative Commons Attribution 4.0 International License, which permits use, sharing, adaptation, distribution and reproduction in any medium or format, as long as you give appropriate credit to the original author(s) and the source, provide a link to the Creative Commons licence, and indicate if changes were made. The images or other third party material in this article are included in the article's Creative Commons licence, unless indicated otherwise in a credit line to the material. If material is not included in the article's Creative Commons licence and your intended use is not permitted by statutory regulation or exceeds the permitted use, you will need to obtain permission directly from the copyright holder. To view a copy of this licence, visit http://creativecommons.org/licenses/by/4.0/. The Creative Commons Public Domain Dedication waiver (http://creativeco mmons.org/publicdomain/zero/1.0/) applies to the data made available in this article, unless otherwise stated in a credit line to the data. 
The second cell type involved in the regulation of the NVU is the pericyte. These cells share the inner basement membrane with BECs and are directly connected to the endothelial cells via peg-socket junctions, which are composed of connexins and N-cadherin [10]. Via these peg-socket junctions, there is a direct exchange of ions, metabolites, and other small molecules. Another important function of pericytes is the regulation of the vessel diameter, which in its turn regulates the cerebral blood flow (CBF) $[11,12]$. Subsequently, the CBF rate can influence the rate of exchange of molecules crossing the BBB.

The next cellular component of the NVU is the astrocyte. Within the CNS, astrocytes have multiple functions, including maintenance of ion-water homeostasis, support of myelination, regulation of glutamate transport and synthesis, enabling synaptic plasticity, control of immune reactions, and promotion of neurite outgrowth [13-16]. At the NVU, perivascular astrocytes are connected with their endfeet to the outer (glial) basement membrane. These endfeet are specialized and polarized structures containing orthogonal arrays of intramembranous particles (OAPs), which display clusters of the selective water channel aquaporin-4 (AQP4) and the ATP-sensitive potassium channel Kir 4.1. [17]. Under physiological conditions, AQP4 is mainly localized at astrocyte endfeet, regulating water uptake and clearance of the brain parenchyma [16]. Dystrophin-associated proteins, e.g. dystroglycans, and extracellular matrix (ECM) molecules, i.e. laminin and agrin, are crucial in anchoring AQP4 at the astrocytic endfeet [18-22]. Upon traumatic brain injury and/or oedema, astrocytes become reactive and redistribute AQP4 away from astrocytic endfeet [23]. These AQP4 water channels facilitate ion-water homeostasis at the NVU [2, 23-25]. Furthermore, astrocyte-derived soluble factors control the $\mathrm{TJ}$ and transporter expression in BECs and therefore regulate NVU function [24].

Additionally, the basement membrane is a highly organized structure within the NVU. It is comprised of ECM molecules as integrins, laminins, collagen and fibronectin. These are expressed and secreted by the various NVU cellular compartments dependent on the cues from the microenvironment [26]. Finally, microglia also participate in the NVU $[27,28]$. In the developing CNS, microglia regulate the formation of CNS vasculature and the control the neuronal progenitor cell niche [29-31].

Not only is the NVU is a complex structure by itself, but it is also heterogeneous throughout brain regions. Each component of the NVU itself has a unique transcriptome, proteome and epigenetic profile depending on the developmental origin and brain region where it is situated [32-37]. Another important aspect regarding the heterogeneity throughout the human brain is that the capillary density is higher in grey matter (GM) compared to white matter (WM). This finding correlates with energy demand [38].

A large part of the human brain consists of WM and is responsible for establishing the neuroconnectivity that underlies the highly complex and unique behavioral capacities of humans $[39,40]$. The WM comprises myelinated axons, diverse types of glial cells, and blood vessels. The WM is selectively affected in the class of leukodystrophies. Leukodystrophies are characterized by primarily affected WM regardless of the molecular processes involved and the disease course [41]. Before this new definition, leukodystrophies were seen as progressive WM disorders caused by a genetic defect, where myelin was the primary affected structure. The myelin defect observed was either a direct effect on myelin or indirect on oligodendrocytes, the myelin forming cells [42]. Later, magnetic resonance imaging (MRI) pattern recognition paved the way for stratifying patients and subsequent genetic explorations [43]. In the following decades, sequencing techniques also evolved, pathological data became more available and new disease models emerged. These scientific developments have given an enormous boost to the field of leukodystrophies. Usually, the clinical course of leukodystrophies is progressive, and often eventually fatal. So far only symptomatic treatments are available. Therefore, unravelling the underlying mechanisms of these diseases is a priority. As mentioned, the WM comprises different cell types that create a complex network of signalling in synergy, yet each leukodystrophy is caused by a different genetic deficit that results in a distinct WM pathology. Notably, the genetic deficits underlying these diseases are not restricted to myelin- or oligodendrocyte-specific genes. Recent next-generation sequencing studies combined with MRI pattern recognition have shown that a predominant dysfunction of cell types other than oligodendrocytes may drive the WM pathology in leukodystrophies. To distinguish the underlying mechanisms, it is essential to identify distinct pathological hallmarks and the specific cell types affected in this heterogeneous group of diseases. Therefore, a new classification system for leukodystrophies has recently been proposed based on cellular pathology and pathogenic mechanisms [44].

Strikingly, some cellular components that are primarily affected, such as astrocytes, are part of the NVU. The function of the NVU, however, has been overlooked in these diseases. The problem in the diagnosis of leukodystrophies is that MRI with contrast agents is not always common practice in the clinic. Additionally, leakage of contrast agents in MR imaging only highlights gross abnormalities of the BBB. Especially when looking at heterogeneous diseases, such as leukodystrophies, certain features, such as BBB leakage of smaller molecules/ 
ions and structural changes in the brain vasculature, can be overlooked. We recent showed that there is NVU involvement in different leukodystrophies regardless of MRI contrast enhancement or the main cellular component involved in the disease [45]. Furthermore, the tools to study these rare diseases are limited and rely mostly on clinical studies and post-mortem brain tissue. Nowadays, alternative techniques are available with the emerging field of human induced pluripotent stem cells (hiPSCs). Using hiPSCs, complex human neural cell models can be built, such as organs-on-chips and organoids, which better recapitulate the in vivo biology compared to other disease models.

The first aim of this review is to outline the implications for the dysfunction of NVU components in leukodystrophies following the leukodystrophy classification system and how these could be important for disease mechanisms. The second aim is to address the current tools to study NVU mechanisms in leukodystrophies and outline future directions.

\section{Leukodystrophies}

Leukodystrophies are classified into several categories depending on the main cellular mechanism of WM injury and other pathological mechanisms that contribute to the disease progression [44]. In this section, we describe the different leukodystrophy classes, and the key components driving the pathology, and we review the knowledge on how the NVU can contribute to disease. The common denominator in leukodystrophies is selectively affected WM, ranging from lack of myelin to complete WM atrophy. Clinically and pathologically, leukodystrophies are highly heterogeneous, therefore the main MRI characteristics, clinical phenotype, and pathological hallmarks are summarized in Table 1.

Hypomyelinating leukodystrophies are characterized by an impaired developmental myelination in the CNS and possibly also the peripheral nervous system (PNS). Leukodystrophies in this category are both clinically and genetically heterogeneous, yet show similarities [46]. The prototypical hypomyelinating leukodystrophy is Pelizaeus-Merzbacher disease (PMD). PMD is an X-linked disorder caused by changes in PLP1, encoding proteolipid protein 1 (PLP1) and the alternative spliced variant DM20 [47]. PLP1 and DM20 are solely expressed by oligodendrocytes in the CNS and Schwann cells in the PNS and are crucial components of the myelin sheath [48]. Therefore, a disruption in PLP1/DM20 has detrimental effects on the structure and functioning of myelin. Depending on the type of PLP1 mutation, histopathology varies, yet some features overlap. There is a significant decrease in the number of mature oligodendrocytes, resulting in a lack of myelin. Altered levels of PLP1 in PMD induce the activation of the unfolded protein response (UPR), which causes apoptosis of oligodendrocytes and neurons [49-51]. The UPR in oligodendrocytes, however, may not be the only neurodegenerative mechanism underlying PMD. Increased astrogliosis and microgliosis have also been observed in brain tissue from patients with different PMD mutations [52]. An astrocytic pathogenetic role is supported by AQP4 redistribution from the perivascular endfeet [45]. Increased levels of AQP4 and its redistribution facilitate oedema formation, as a result of compromised ion-water homeostasis $[53,54]$. Neuroinflammation, marked by activated microglia, may also play an important role in the pathophysiology of PMD. The role of inflammation and the NVU, however, has not been further investigated in PMD.

In demyelinating leukodystrophies, the development of myelin is supposedly largely unaffected, yet later in life loss of myelin (demyelination) occurs. Metachromatic leukodystrophy (MLD) is a lysosomal sphingolipid storage disorder inherited in an autosomal recessive manner and caused by genetic mutations in the ARSA gene. These result in a deficiency of the enzyme arylsulfatase A (ASA), which is responsible for breaking down sulfatides in the CNS and PNS. Under normal conditions, sulfatides are essential components of myelin, their proper expression being essential for the differentiation of myelinating cells and myelin maintenance. In MLD, accumulation of sulfatides is toxic and results in demyelination. MLD is classified into late-infantile, juvenile, and adult-onset, with disease severity co-varying with age at onset, levels of ASA activity, and type of ARSA mutation [55-58]. Microscopy shows demyelination accompanied by accumulation of sulfatides in the glial cells, neurons, and macrophages. There is a negative correlation between increased demyelination and reactive gliosis in the CNS. The involvement of astrocytes has not been investigated extensively, however, one study has demonstrated AQP4 redistribution [45], hinting towards astrocyte dysfunction. Interestingly, in the perivascular space of especially the WM there is accumulation of lipid-laden macrophages, which may release inflammatory mediators that can affect the BBB function [58]. The NVU of MLD patients, however, has not been investigated to such an extent. In other demyelinating neurodegenerative diseases, such as multiple sclerosis (MS), infiltration of leukocytes has detrimental effects on disease progression as the neuroinflammatory cascade worsens and leads to further neurodegeneration together with further BBB breakdown [59].

Another category of leukodystrophies is characterized by myelin vacuolization. In the past years, due to wholeexome and whole-genome sequencing, the number of unclassified leukodystrophies has decreased, resulting in 


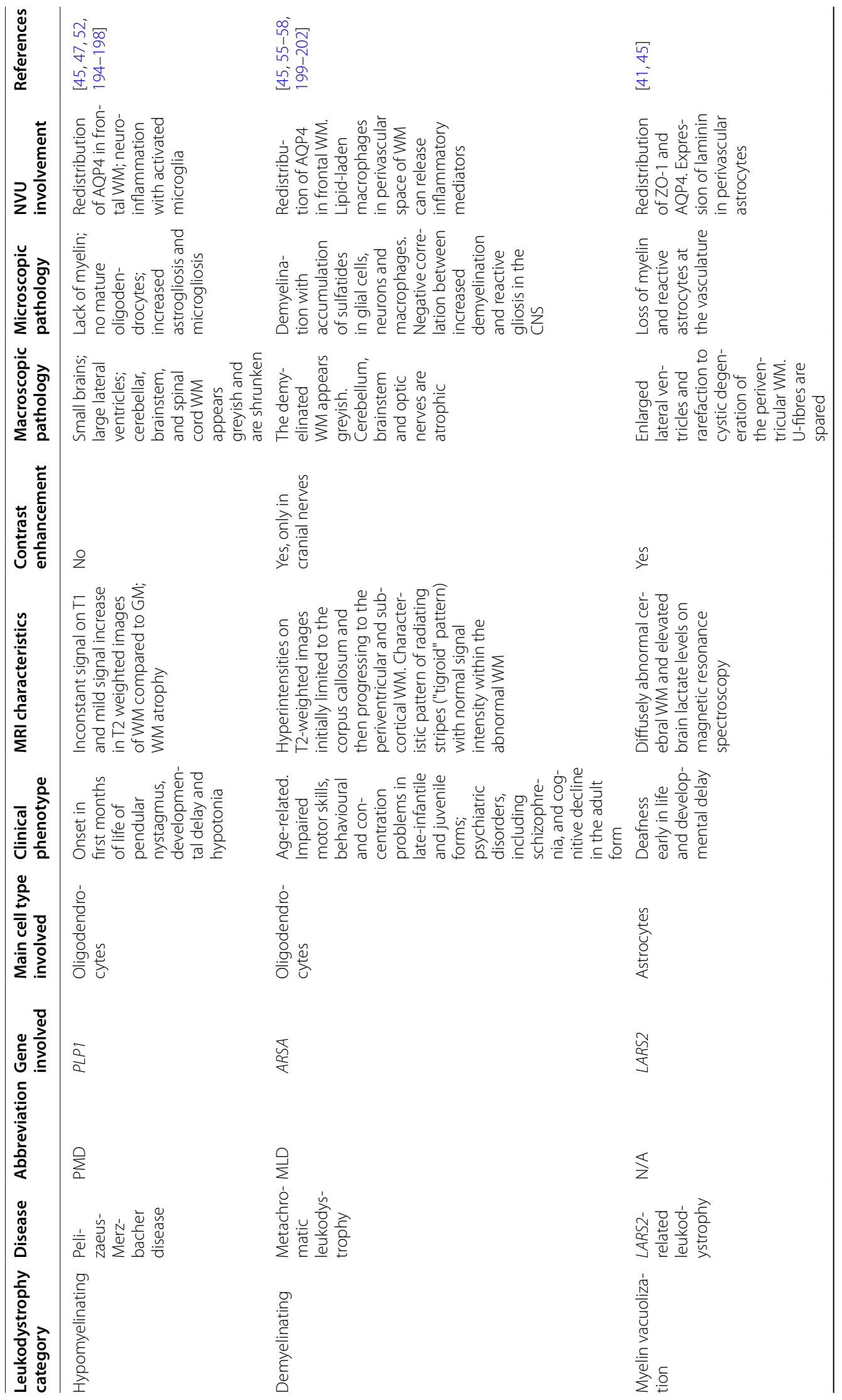




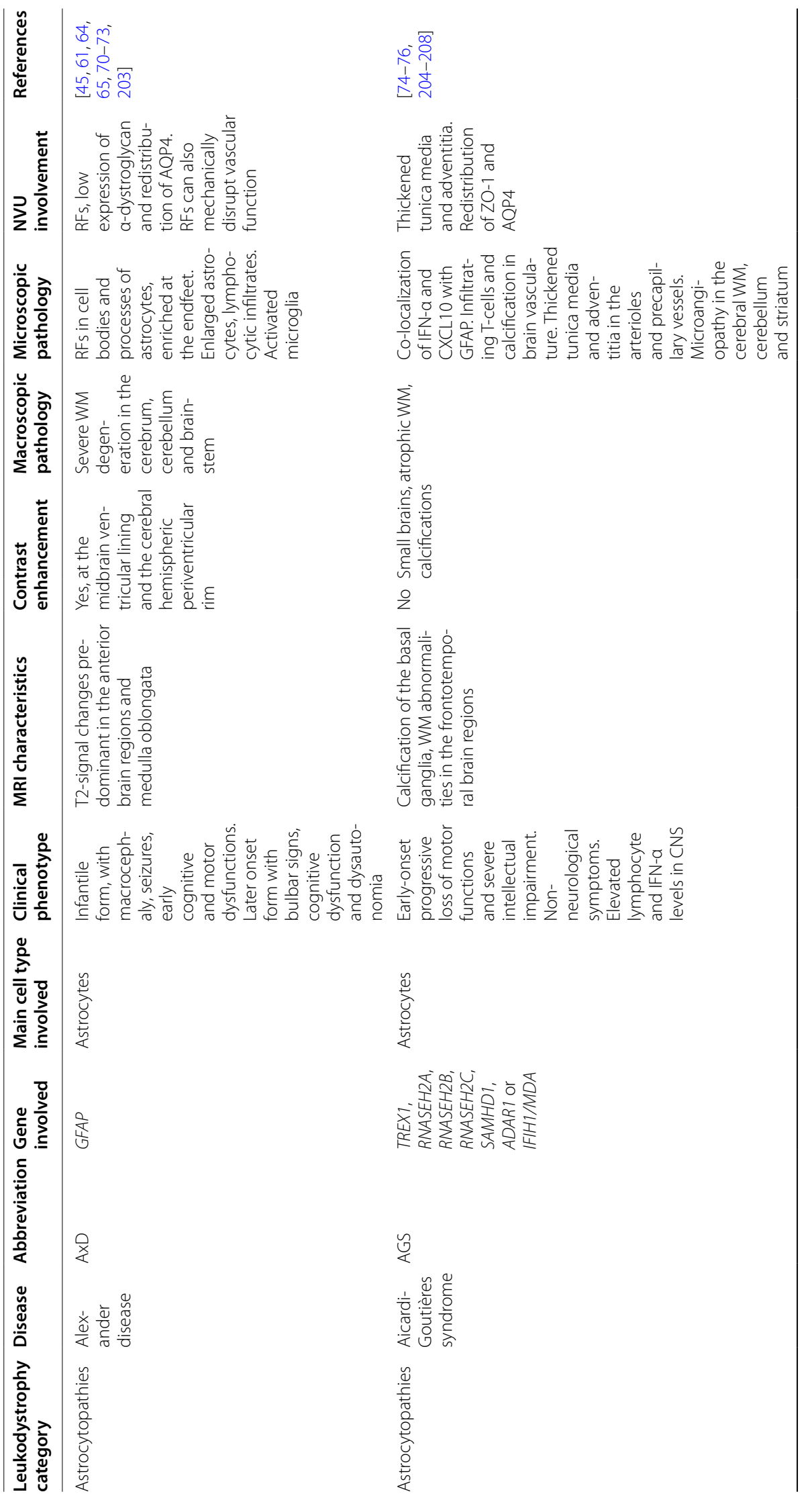




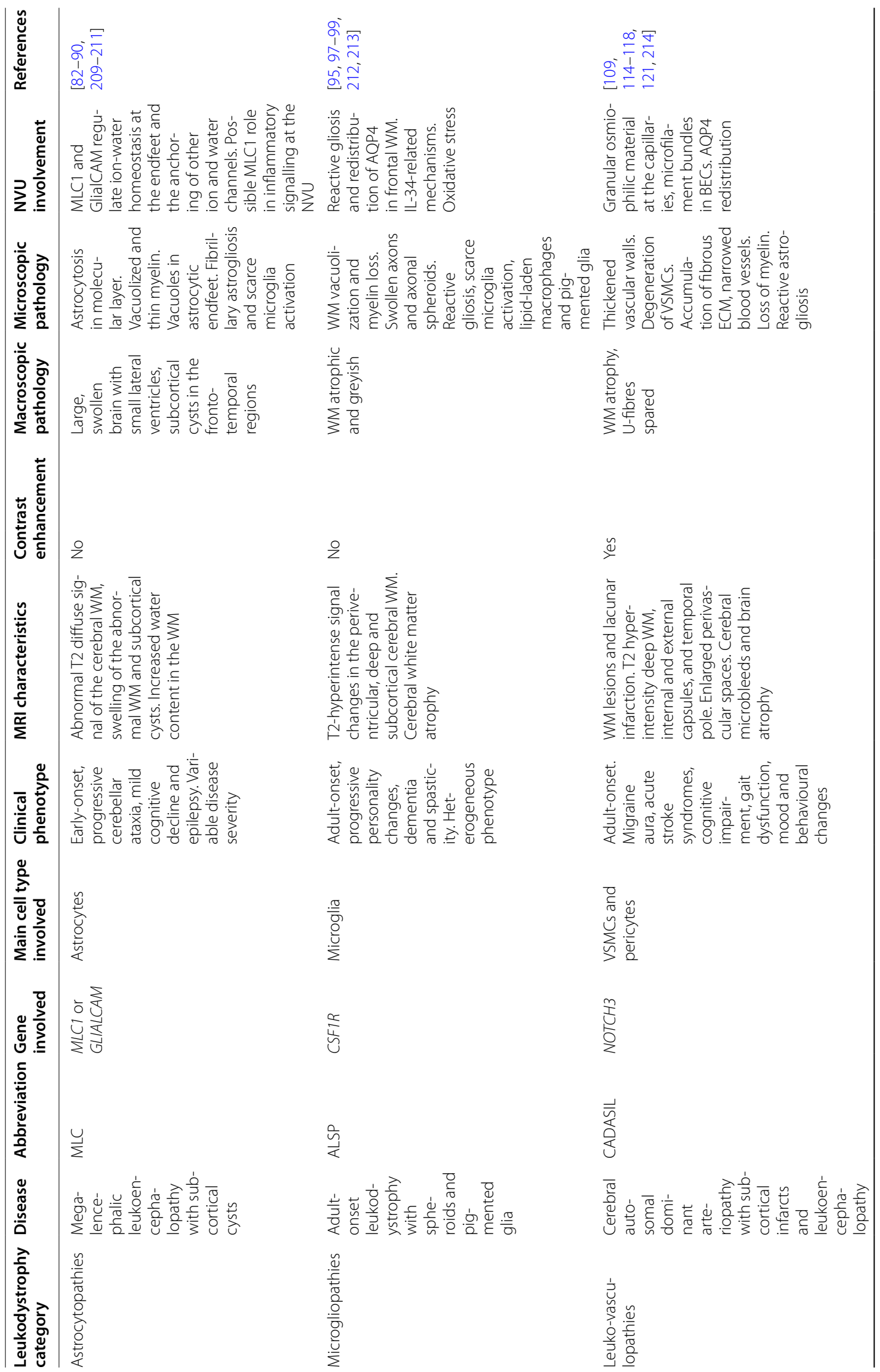




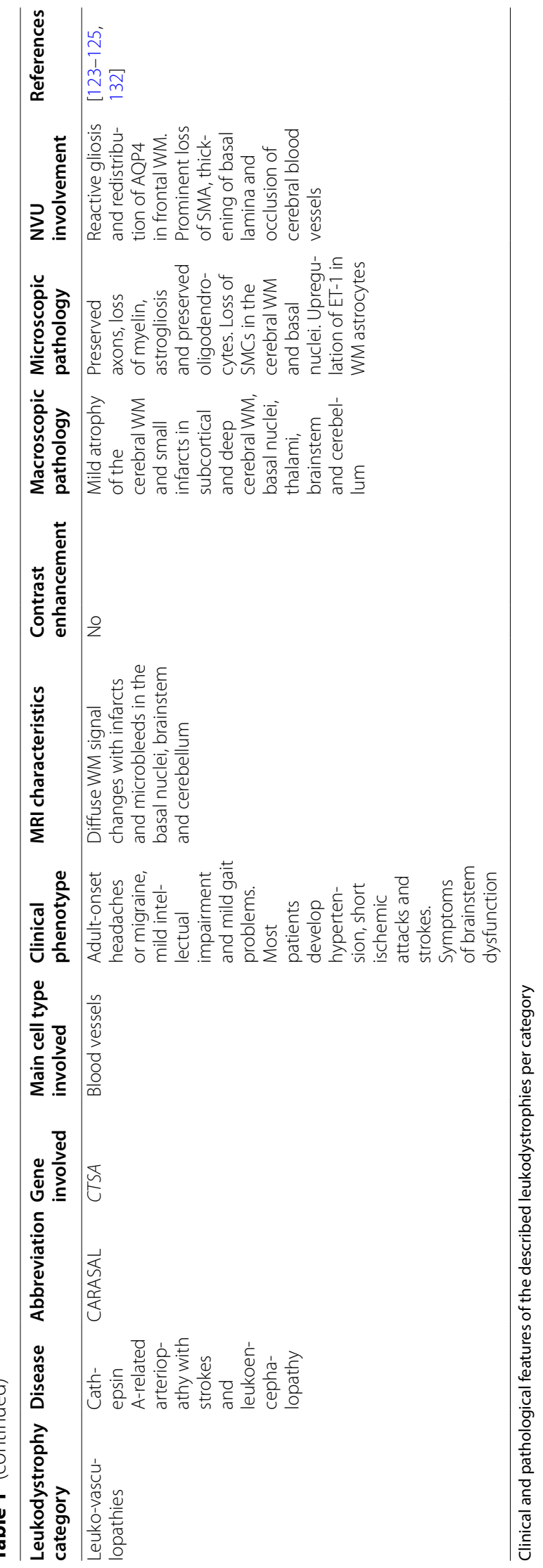


the discovery of a class of leukodystrophies that has deficits in the mitochondrial protein translation [41]. These leukodystrophies are mostly mitochondrial diseases with leukoencephalopathy caused by different mutations in genes related to mitochondrial functioning. Recently, biallelic mutations in LARS2 and KARS, which encode for aminoacyl tRNA synthases (aaRSs), were identified as a cause of mitochondrial leukodystrophy [41]. Post-mortem pathological examination of a LARS2-related leukodystrophy patient showed loss of myelin, with U-fibres relatively spared. Observation of reactive astrocytes was mostly restricted to the blood vessels, yet reactive gliosis was relatively scarce compared to the degree of WM damage [60]. Pathological investigation of the NVU revealed redistribution of the $\mathrm{TJ}$ protein zona occludens 1 (ZO-1) and of AQP4 [45], demonstrating respectively $\mathrm{BEC}$ and astrocytic dysfunction.

Astrocytophathies are leukodystrophies caused by mutations in astrocyte-specific genes or in which astrocytes significantly contribute to the disease mechanisms. Alexander disease $(\mathrm{AxD})$ is the prototypic astrocytopathy. It is due to mutations in GFAP, which is a cytoskeletal intermediate filament protein that in the CNS is specifically expressed in astrocytes [61-63]. Gain-offunction mutations in GFAP cause overexpression of GFAP [64]. Overexpression of GFAP in AxD astrocytes results in the formation of Rosenthal fibres (RFs), which are intracellular protein aggregates that also contain heat shock proteins [65]. RFs cause different cellular dysfunctions, including activation of cellular stress pathways [66], inhibition of proteasome activity [67], and changes in the regulation of autophagy $[68,69]$. Not only are the RFs observed in cell bodies, but also in the endfeet and processes of astrocytes, in subpial zones, and around blood vessels where they correlate with $\mathrm{BBB}$ dysfunction and contrast enhancement on MRI. A recent study has shown that in $\mathrm{AxD}$, there is astrocytic redistribution of AQP4 and low expression of $\alpha$-dystroglycan around affected blood vessels [45]. This astrocytic endfeet pathology could mechanically contribute to NVU dysfunction. Besides the formation of RFs, morphology of WM astrocytes is also altered and the astrocytes are enlarged. Also, redistribution of $\mathrm{ZO}-1$ indicates that $\mathrm{BECs}$ are dysfunctional. Whether this is a direct consequence of astrocytic dysfunction is still unclear [45]. Neuroinflammation conceivably also plays an important role in the pathology of $\mathrm{AxD}$ as perivascular lymphocytic infiltrates have been reported [70-73]. In fact, downstream effectors of the NF-kB inflammatory signalling pathway are significantly upregulated and accompanied by an amount of activated microglia and infiltrated monocyte-derived macrophages in the brains of an $\mathrm{AxD}$ mouse model. The same study also confirmed the activation of microglia and macrophages in the brains of AxD patients together with perivascular and intraparenchymal infiltrating $\mathrm{T}$-cells [71]. Yet, the exact role of T-cell infiltration and neuroinflammation in AxD remains an enigma. As mentioned, perivascular accumulation of RFs is a hallmark of $\mathrm{AxD}$ pathology, therefore neuroinflammation could be caused by a disruption of the NVU.

Aicardi-Goutières syndrome (AGS) is an autoimmune astrocytopathy characterized by overproduction of interferon alpha (IFN- $\alpha$ ), a cytokine activator of the innate immune response. AGS is caused by loss of function mutations in seven genes, including TREX1, RNASEH $2 A, \quad R N A S E H 2 B, \quad R N A S E H 2 C$, SAMHD1, $A D A R 1$ and IFIH1/MDA, the inheritance pattern of which is mostly autosomal recessive. Mutations in all these genes result in upregulation of IFN- $\alpha$ [74, 75]. Astrocytes are the main cells that produce IFN- $\alpha$ in the CNS and examination of post-mortem brains from AGS patients revealed co-localization of IFN- $\alpha$ and C-X-C motif ligand (CXCL) 10 with GFAP [76]. A study using an in vitro setup with human neural stem cellderived astrocytes showed that chronic IFN- $\alpha$ exposure reduces cell proliferation while it simultaneously promotes astrocyte reactivity. Correspondingly, genes that are important in the maintenance of WM integrity were altered after exposure to IFN- $\alpha$ [77]. A transgenic mouse model that solely produces IFN- $\alpha$ in astrocytes shows a similar clinical phenotype as AGS patients, including calcium depositions in the basal ganglia, neurodegeneration, seizures, and encephalopathy [78, 79]. Not only does the release of IFN- $\alpha$ in the CNS play an important role in AGS, but also the peripheral inflammation can cross-talk with the CNS. One study indicated an increase of dendritic cells (DCs) in the CSF of AGS patients, more specifically plasmacytoid DCs, which are known to produce large amounts of IFN- $\alpha$ compared to other cell types [80]. Moreover, neuropathology revealed infiltrating T-cells and blood vessel calcifications. More specifically, microangiopathy in the AGS cerebral WM, cerebellum and striatum is accompanied by a thickened tunica media and adventitia in the arterioles and precapillary vessels. Calcification of these cell types can impede vascular constriction and therefore impair CBF, which is crucial for brain functioning [81]. Furthermore, astrocytes have redistributed AQP4 channels, indicating an alteration in ion-water homeostasis, and redistributed $\mathrm{ZO}-1$ proteins, indicating BEC dysfunction [45]. Both in vivo and in vitro data support the notion that astrocytes play a key role in the IFN- $\alpha$ signalling and its downstream pathways and there is strong evidence for a disrupted NVU and BBB in AGS, which could contribute to the pathology. 
Megalencephalic leukoencephalopathy with subcortical cysts (MLC) is an infantile-onset leukodystrophy characterized by onset of macrocephaly in early infancy. Recessive mutations in the $M L C 1$ and GLIALCAM genes, respectively encoding MLC1 and GlialCAM/ MLC2A, cause MLC [82, 83]. Pathological examination reveals astrocytosis in the molecular layer of the cortex. The amount of myelin within the WM is normal, yet the morphology of the myelin is altered by the presence of countless vacuoles. Also, the myelin sheaths are abnormally thin. Intracytoplasmic vacuoles are also abundantly present in astrocytic endfeet connected to the capillaries. The WM exhibits fibrillary astrogliosis and scarce microglia activation [84-87]. MLC1 expression in the CNS is restricted to the cell membrane of GM and WM astrocytes, ependymal cells, and cerebellar Bergmann glia. In astrocytes, MLC1 is specifically localized in the endfeet at the NVU and glia limitans. MLC1 is important for the regulation of CNS ion-water homeostasis, explaining the increased water content in the patient's brains [83, 8890]. A mouse model of MLC revealed that other ion and water channels important at the NVU, including Kir4.1, CLC-2, and AQP4, are also redistributed or altered in expression, indicating that MLC1 regulates the expression of other proteins at the BBB [91]. Not only a defect in $M L C 1$ but also in GLIALCAM can result in MLC. GlialCAM is a chaperone protein for MLC1 and colocalizes with MLC1 in astrocytes. It is also found in oligodendrocytes and axons. As MLC1 proper localization is dependent on GlialCAM, disruption of GlialCAM functioning results in MLC1 dysfunction causing a clinically similar phenotype [82, 92]. Interestingly, a recent study investigated the expression of MLC1 across diseases with a strong neuroinflammatory component: Alzheimer's disease (AD), MS, and Creutzfeldt-Jacob disease. Here MLC1 upregulation was shown across regions with strong neuroinflammation and increased astrocytosis. Also, the authors demonstrated that MLC1 protein reacts to inflammatory signals, in particular IL-1 $\beta$, through downregulation of signalling involved in astrocyte activation [93]. Considering that these neuroinflammatory diseases [93] have a disrupted BBB and that MLC1 localization is mainly at the vasculature, it is highly likely that the BBB and the NVU are also disrupted in MLC. Yet, to what extent has to be investigated.

Microgliopathies are leukodystrophies caused by mutations in microglia-specific genes or in which microglia significantly contribute to the disease process. In different neuroinflammatory conditions, microglia secrete inflammatory cytokines that contribute to disease severity. Also, they play a crucial role in (re)modelling synaptic circuits, myelin maintenance, myelin debris clearance, and neuronal reaction upon injury. Adult-onset leukodystrophy with spheroids and pigmented glia (ALSP) is caused by mutations in CSF1R encoding colony-stimulating factor (CSF) 1 receptor [94, 95]. Microscopy reveals WM vacuolization and myelin loss. Additionally, there are swollen axons and axonal spheroids present in the WM lesions. These spheroids are immunopositive for amyloid precursor proteins and phosphorylated neurofilaments [96]. Microglia depletion is also seen, together with lipidladen macrophages and pigmented glia [97-99]. Reactive gliosis is observed in the WM together with AQP4 redistribution, indicating astrocytic involvement in the pathology [45]. CSF1R is a tyrosine kinase receptor crucial for the functioning of microglia. Together with its ligands, CSF1 and IL-34, it regulates production, differentiation, activation, and chemotaxis of microglia and macrophages [100, 101]. IL-34 is an important controller of $\mathrm{BBB}$ maintenance and TJ regulation [102], yet whether this pathway is disrupted in ALSP is not known. Oxidative stress also plays a role in ALSP, since high levels of ceroid and iron are found in the macrophages [103-105]. Reactive oxygen species (ROS) indeed induce damage to the $\mathrm{BBB}$ in the context of other neurodegenerative disorders and thereby worsen the pathology, yet how this process is regulated in ALSP is unknown.

Leuko-vasculopathies are characterized by involvement of the small blood vessels. These small blood vessels can be at all levels of the CNS vascular tree from the penetrating arteries to the capillary bed. Cerebral small vessel diseases (CSVDs) cause neurofunctional loss and severe cognitive decline usually later in life. CSVDs display a dysfunctional BBB with pericyte degeneration and swelling of the astrocytic endfeet [106-108]. Cerebral autosomal dominant arteriopathy with subcortical infarcts and leukoencephalopathy (CADASIL) is the most common CSVD and is caused by mutations in NOTCH3, which encodes a transmembrane receptor that is predominantly expressed by vascular smooth muscle cells (VSMCs) and pericytes [109]. The NOTCH family consists of proteins involved in cell cycle regulation, migration, differentiation, proliferation, and synaptic plasticity throughout the brain [110]. NOTCH3 signalling is in particular important for cell fate specification during embryonic development [111] together with several vascular-related processes in both development and adulthood [112-114]. Mutations of NOTCH3 in CADASIL change the number of cysteine residues in the extracellular domain of $\mathrm{NOTCH} 3$, which then accumulates at the blood vessels. These protein aggregates form, together with other proteins and ECM components, granular osmiophilic material (GOM) that deposits extracellularly in the brain and peripheral organ vasculature, occluding the blood vessels [115]. Indeed, studies have shown a decreased CBF in both patients and animal models accompanied by BBB leakage [116, 117]. 
Moreover, extensive WM astrocytopathy with AQP4 redistribution is observed together with loss of VSMCsindicating further NVU involvement in CADASIL $[115,118]$. The exact underlying mechanism of NOTCH3 dysfunction in CADASIL, however, is still under debate, since some studies using NOTCH3 knockout mice show that GOMs are not necessary to develop the disease [119-121]. Therefore, more innovative models are needed to study the pathophysiology.

Cathepsin A-related arteriopathy with strokes and leukoencephalopathy (CARASAL) is a recently identified adult-onset leukodystrophy caused by a dominant mutation in the CTSA gene encoding for cathepsin A (CathA). CathA is expressed in all tissues throughout the mammalian body but is enriched in the endothelium [122]. CathA is a lysosomal serine protease that degrades intracellular and extracellular substrates and protects $\beta$-galactosidase and neuraminidase-1 from intralysosomal proteolysis, thereby stabilizing lysosomal activity. CathA is also involved in ECM formation and stabilization [123, 124]. Axons appear preserved, and loss of myelin, astrogliosis, and preservation of oligodendrocyte density are observed [125]. At the arteriolar branches throughout the cerebral WM and basal nuclei, the vessel walls display asymmetrical fibrous thickening and loss of smooth muscle cells accompanied by occlusion of the lumen. There is a prominent loss of expression of smooth muscle actin (SMA). In some vessels, there is also thickening of the basal lamina [125]. SMA is also a marker for pericytes, pointing towards pericyte dysfunction in this disease. Pericytes might need SMA to contract properly [126-128], thereby regulating the CBF. Changes in the CBF rate could induce dysfunction of the $\mathrm{BBB}$ and decrease the quantity of nutrients entering the brain parenchyma $[128,129]$. One of the many functions of CathA is the degradation of Endothelin-1 (ET-1), a small signalling peptide regulating vasoconstriction. ET-1 also regulates multiple facets of oligodendrocyte development and response to injury [130, 131]. ET-1 is upregulated in the WM astrocytes of CARASAL patients and results in dysregulation of the developmental programming of oligodendrocyte progenitor cells (OPCs) in the subventricular zone (SVZ) [132]. Further astrocytic involvement has been shown in a recent study that demonstrates the redistribution of AQP4 [45]. This indicates that also ion-water homeostasis in CARASAL could be disrupted. The exact role of CathA dysregulation in the context of NVU functioning, however, remains an enigma.

\section{In vitro models to study the NVU contribution in physiology and disease}

The brain is arguably the most complex organ of the human body, and due to that, there is still much to unveil about the molecular mechanisms and cellular interactions that occur both in homeostasis and disease. Much of what is known about neural development and degeneration has been derived from human post-mortem material and animal models of neurological diseases, such as AD [133], Parkinson's Disease (PD) [134], and MS [135]. Yet, differences in gene expression, signalling pathways, protein homology, brain architecture, and neuronal circuit complexity between animals and humans reduce the predictive capacity of in vivo models [136-139]. The ratio of WM to GM is also considerably lower in rodents than in humans, a feature that naturally hinders the study of leukodystrophies in these models [140]. These limitations encouraged the development of in vitro strategies that exploit human source material to directly model human physiology.

Leukodystrophies have been studied for over a 150 years, yet the NVU in these diseases has been overlooked. The first step in the study of leukodystrophies is a proper diagnosis. Nowadays, with the help of MR pattern recognition, new imaging tools, next-generation sequencing, and availability from data worldwide, this process is more rapid and precise. The next important tool in studying leukodystrophies is a pathological examination of human post-mortem tissue. Pathological findings are crucial in determining what underlying mechanisms contribute to disease causation and progression. There are some issues, however, with using human post-mortem tissue. The most important one is that only the end-stage of the disease can be studied. Since leukodystrophies are highly heterogeneous in disease progression and age of onset, crucial disease hallmarks in disease development can be overlooked, especially in the context of NVU dysfunction, which is a process that occurs over time. To overcome these hurdles, proper disease modelling comes into play. In the next sections, we will discuss the current human in vitro models that are used to study the NVU, particularly in the context of leukodystrophies, addressing their advantages and disadvantages and identifying emergent models that better recapitulate the NVU and $\mathrm{BBB}$ in physiology and disease. An overview of the in vitro models that will be discussed is displayed in Fig. 1.

\section{Primary cells and cell lines}

Cultures of human primary cells isolated from postmortem tissues or biopsy samples provided a primary solution for studying the diseases in a human genetic 


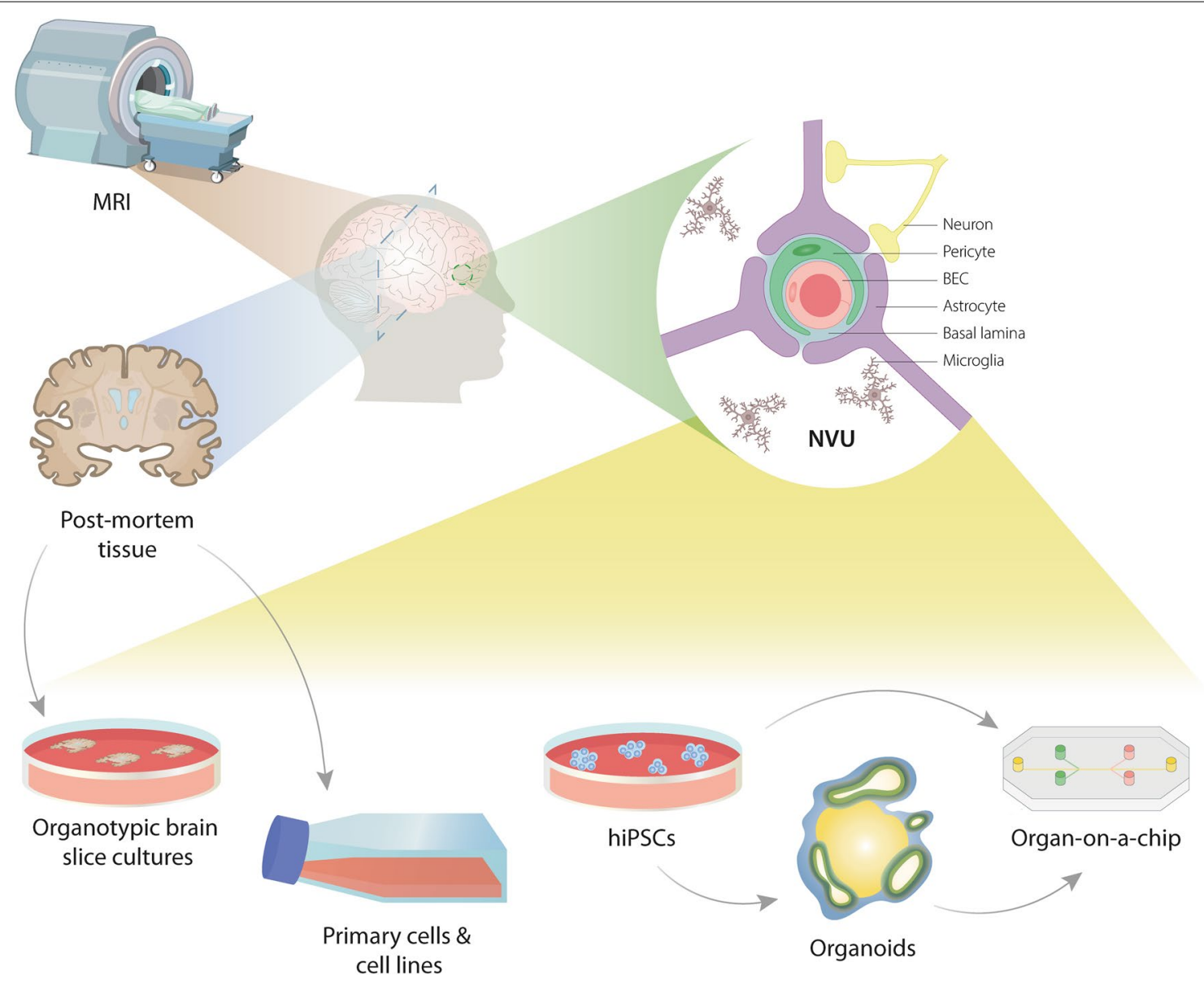

Fig. 1 Schematic representation of models to study the NVU in leukodystrophies in humans. The first step of studying leukodystrophies is in a clinical setting, using MRI and next-generation sequencing for initial diagnosis, monitoring disease progression and treatment of patients. Since most leukodystrophies are fatal, post-mortem analysis and post-mortem tissue-derived primary cells, immortalized cell lines, and organotypic slice cultures are valuable tools to distinguish primary cellular processes involved in the pathogenesis. Finally, hiPSC-based models can contribute to investigating the molecular pathways and dynamics at the NVU during disease development and test therapeutic interventions. Together, clinical and basic research can contribute to understanding disease mechanisms in leukodystrophies

background [141]. However, the limited access, scarce availability, especially in rare disorders as leukodystrophies, and reduced capacity for in vitro expansion, together with phenotypical changes when cultured in vitro, triggered the search for new solutions [142, 143]. Immortalized cell lines, including tumor cell lines [144], overcome the expansion problem but fail to adequately mimic the in vivo cellular behaviour [145]. Even so, all these approaches are still used to investigate BBB physiology and dysfunction $[146,147]$, angiogenesis in the CNS [148], and the molecular cues exchanged by endothelial and neural cells [149]. The Transwell assay is the most frequently used in vitro assay for replicating the BBB. In this co-culture system, a BEC monolayer is cultured on the apical side of a membrane insert, while supporting cell types, such as pericytes and astrocytes, are cultured on the basal side of the same membrane and also on the bottom of the well. Although this system is ideal for investigating paracrine and autocrine factors secreted by the involved cell types, it fails to model proper heterotypic cell-cell contacts, as well as shear stress and cylindrical geometry, characteristics of blood vessels in vivo [150].

\section{Organotypic slice cultures}

Organotypic slice cultures are an extensively used ex vivo strategy to study the brain, and specifically neurovascular crosstalk $[151,152]$. Their main advantage is the ability to preserve structural and synaptic organization [153] in a biologically relevant 3D environment. Numerous applications have been reported, including long-term 
live imaging, multi-electrophysiological stimulations and recordings, and neurotoxicity assays [153]. It was demonstrated that brain capillaries can survive in organotypic brain slices and, even though they do not present blood flow and are no longer functional, they might still secrete a number or molecules that may influence other cell types in the culture [153]. In an attempt to model the $\mathrm{BBB}$, researchers have cultured brain slices on top of a monolayer of BECs and reported some BBB characteristics in situ [154]. Others tried to understand if the functional and structural properties of the NVU and BBB were preserved in slice cultures [155]. Although immunostainings revealed the maintenance of NVC and vasomotion, BBB intactness can hardly be studied in slices, since the preparation opens up and damages the vessels, eliminating their barrier functionality. Moreover, these slices usually come from animal models, which are not the most reliable replica of human biology [156], while sample scarcity imposes a considerable limitation when studying rare diseases.

\section{Human induced pluripotent stem cells}

The advent of hiPSCs revolutionized biomedical research and became a major tool for studying brain diseases. hiPSCs can differentiate into any cell type and self-renew indefinitely. Due to this, they overcome the expansion and availability limitations of primary cells while maintaining the biologically relevant human context and safeguarding the genetic background of the patient. hiPSCs are induced by over-expressing four genes (Yamanaka's factors) in easily accessible cells, such as skin fibroblasts $[157,158]$. This technology opens up new possibilities to study rare diseases, such as leukodystrophies, for which research is often hampered due to scarcity of biological material.

One of the biggest limitations of hiPSCs is the difficulty to generate fully mature and specific cell types, like excitatory and inhibitory neurons [159] or white and grey matter astrocytes [160]. However, researchers are working hard to tackle this problem and protocols have been developed for the production and maturation of many cell types $[161,162]$.

Another main limitation of hiPSCs is the resetting of the epigenetic memory. hiPSCs harbour residual epigenetic information specific to their original somatic tissue, which favours their differentiation along lineages associated with the donor cell, while inhibiting alternative cell fates [163]. Nevertheless, several studies have reported the generation of hiPSCs in a more primitive developmental stage, named naïve pluripotency, where the global genome hypomethylation is similar to an early human embryo [164].
In regards to the NVU recapitulation using hiPSCs, it is crucial to acknowledge the heterogeneity of the brain vasculature and surrounding parenchyma, for example in grey and white matter. Regional differences exist in vascular density and function, orientation and permeability, phenotype and function of astrocytes, the ratio of neuronal to non-neuronal cells, and BEC gene expression [165]. Ideally, these distinct aspects must be reflected in the in vitro $\mathrm{BBB} / \mathrm{NVU}$ model that is used or developed according to the targeted disease, meaning that there is no accurate "one size fits all" BBB model and that the region where the disorder takes place should be taken into account. In the context of leukodystrophies, there is a current need for protocols to generate white matterspecific cell populations, which are already acknowledged as being functionally and phenotypically different from their grey matter counterparts [165].

\section{Organoids}

Using hiPSCs, it is possible to engineer several different strategies to explore brain homeostasis and disorders. A major breakthrough is the technique to culture cerebral organoids [166, 167]. The definition of organoid is still quite controversial, and some researchers struggle with the line between a spheroid and an organoid. Even so, it is generally agreed that, while spheroids are 3D cultures consisting of cell aggregates established from primary cells or immortalized cell lines, organoids are stem cellderived 3D cell aggregates that self-organize to recapitulate some of the endogenous tissue characteristics [168]. These 3D structures constitute a physiologically relevant tool for drug screening, developmental biology, and pathology, by allowing for cell-cell and cell-matrix interactions in an in vivo-like organization, in contrast to $2 \mathrm{D}$ systems $[169,170]$.

\section{Organ-on-a-chip}

Microfluidic cell culture devices, also known as organson-chips (OOCs), have emerged as a system capable of reliably replicating the complex three-dimensional architectures of tissues and organs, including cell-cell interactions and mechanical cues to which the tissues are subject [171]. OOCs are microfluidic systems for cell culture in micrometer-sized perfusable channels, intended to model biological functions and events happening in the different tissues and organs [172]. These chips are usually divided into chambers that are interconnected by microgrooves, allowing for axonal alignment, interactions between different cell types cultured on each of the chambers, or the establishment of molecular spatiotemporal gradients. 
OOCs have a substantial number of favourable characteristics as an in vitro model of human physiology or pathologies. One of the most important is the possibility to design culture strategies in which a variety of parameters (cell types and relative positioning; transcellular gradients; cellular alignment; mechanical forces; flow levels and patterns) can be controlled independently while running real-time high-resolution imaging of molecular phenomena in a physiologically relevant microenvironment [172]. The experimental and design flexibility [173] allows precise cell positioning to promote interactions between different cell types while integrating live analytical and microscopical assays.

The ability to perform perfusion cultures with controlled laminar flow in OOCs is especially important for studying the NVU since it can be used to mimic blood flow in microvessels. Besides being directly related to the vasculature, blood flow boosts the function, survival, and differentiation of several NVU-related cell types [174176]. The inclusion of flow also enables testing of molecular signals and gradients, as well as paracrine/angiocrine cues, which are critical players in BBB maintenance and dysfunction. On the other side, the low number of cells necessary for the culture and the reduced reagent consumption [173] improve the cost efficiency of the system. This feature, allied to the scalability towards parallel automated large-scale platforms [177], provides the basis for the valuable high-throughput characteristic of microfluidics approaches. The smaller relative volume also minimizes dilution of secreted factors that may be critical in the communication between neural and endothelial cells. Moreover, cell phenotypes are more likely to be preserved, since sizes and cell confinement are similar to the in vivo NVU microenvironment [178].

Thus, OOCs represent compelling biological models for studying the underlying pathological mechanisms of several diseases and investigating the function and operation of human tissue structures, including the BBB and the NVU. By combining OOCs with hiPSC technology, it is possible to create a patient-specific tool for precision medicine or to establish a disease model for drug screening or fundamental research. It has already been reported in-chip co-cultures of iPSC-derived BECs with isogenic neural cells (neurons, astrocytes, and neural progenitor cells) [179], astrocytes [180], or pericytes [181], which gradually gets the ultimate goal of building an in vitro human NVU closer to reality.

\section{D bioprinting}

3D bioprinting has been appointed as a promising area to produce a complex three-dimensional in vitro NVU in which the contribution of each cell type can be studied at the cellular and molecular levels. Different cell types can be embedded in bioinks-cell-supportive hydrogels with shear-thinning properties-and bioprinted to produce NVU models with various components. Bioprinting enables accurate placing of the vascular and neural cells to establish proper interactive interfaces that recreate the in vivo condition [182].

One of the biggest challenges of $3 \mathrm{D}$ printing is the development of bioinks. These hydrogel matrices must have mechanical properties capable of being 3D printed and mimicking the ECM and, at the same time, be suitable for cell viability and growth, while allowing the synthesis and deposition of their own native ECM, to properly replicate the natural microenvironment [183]. For an NVU model specifically, the bioink must enable cellular adhesion and migration, neurogenesis, and vascularization, as well as interactions between vascular and neural components. Besides this complicated bioink formulation, biomimetic 3D bioprinting also poses other challenges, namely the biological complexity of all physical and chemical factors that need to be reproduced and the extensive amount of time needed, since some period of maturation is typically required following tissue printing [184].

\section{Vascularized organoids and organoid-on-a-chip}

Vascularized brain organoids are arising as an interesting approach to assess the cerebral neurovascular crosstalk and mimic the NVU. Different strategies are being developed to produce this kind of organoids. In a pioneer study, whole-brain organoids were generated using patient-derived hiPSCs and then embedded in Matrigel containing isogenic iPSC-derived ECs [185]. In a similar rationale, human umbilical vein endothelial cells (HUVECs) were co-cultured with human embryonic stem cells (hESCs) that were further differentiated into cortical neurons [186]. Using a different approach, researchers induced ETV2 expression on hESCs to guide their differentiation towards the endothelial phenotype and formation of vascular-like structures in human cortical organoids [187]. Recently, a perfusable platform was developed to generate neurovascular organoids from brain organoids surrounded by hiPSCderived ECs and pericytes [188]. Nevertheless, to date, none of the strategies formed robust lumenized and perfusable capillary-like structures inside the brain organoid nor demonstrated BBB hallmarks such as high TEER, low permeability and expression of $\mathrm{BBB}$ markers.

Another strategy that has been recently explored is the integration of organoids in OOC technology. In these organoids-on-a-chip, the advantages of both systems come together in a synergistic model that recapitulates 
the human body to the fullest. This has been recently done with different organoids, including the brain, for toxicity assessment [189], organoid maturation [190] and vascularization [188]. By constructing a chip with an appropriate design and integrating the right cell types, it is possible, now more than ever, to recapitulate the complexity of the NVU in vitro.

\section{Future perspectives and challenges in leukodystrophies}

There is currently a lack in the availability of advanced human in vitro NVU models for leukodystrophies and other rare diseases, which hinders the development of efficient treatments. Researchers have already reported the generation of region-specific brain organoids-cortex [191], forebrain [192], midbrain [192], hypothalamus [192] and cerebellum [193]-which led to a major improvement on the readout for some region-specific disorders. However, no successful generation of white matter-only organoids was reported so far, which could widely improve the study of and drug development for leukodystrophies. In a different approach, due to their monogenic nature, it would be straightforward to create iPSC lines for the different leukodystrophies by targeting the single disease-causing gene. After this, one should be able to engineer reliable in vitro models of leukodystrophies to further explore the contribution of the NVU and the BBB in these diseases.

By unravelling the cellular and molecular mechanisms behind this intricate crosstalk, new drug candidates may arise, which can then be screened using the same model and tested in a patient-specific manner. A systematic analysis over time can also clarify whether changes in the NVU are a result of the disease, a cause of injury, or an exacerbatory factor of the primary dysfunction, which is not possible to assess in post-mortem studies.

Naturally, optimizing the experimental conditions for such complex models may take time and requires knowhow from different fields of research. Therefore, it is crucial to have an interdisciplinary approach to the issue and to establish collaborations with colleagues from distinct backgrounds, to wisely design a robust and reliable model that can effectively replicate human nature.

\footnotetext{
Abbreviations

aaRSs: Aminoacyl tRNA synthases; ABC: ATP binding cassette; AD: Alzheimer's disease; AGS: Aicardi-Goutières syndrome; AJ: Adherens junction; ALSP: Adultonset leukodystrophy with spheroids and pigmented glia; AQP4: Aquaporin-4; ASA: Arylsulfatase A; AxD: Alexander disease; BBB: Blood-brain barrier; BEC: Brain endothelial cell; CADASIL: Cerebral autosomal dominant arteriopathy with subcortical infarcts and leukoencephalopathy; CARASAL: Cathepsin A-related arteriopathy with strokes and leukoencephalopathy; CathA: Cathep$\sin$ A; CBF: Cerebral blood flow; CNS: Central nervous system; CSF: Cerebrospinal fluid; CSF1: Colony stimulating factor 1; CSF1R: Colony stimulating factor 1 receptor; CSVD: Cerebral small vessel disease; CXCL: C-X-C motif ligand; EC:
}

Endothelial cell; ECM: Extra-cellular matrix; ET-1: Endothelin-1; GFAP: Glial fibrillary acid protein; GM: Gray matter; GOM: Granular osmiophilic material; hESCs: Human embryonic stem cells; hIPSCs: Human induced pluripotent stem cells; HUVECs: Human umbilical vein endothelial cells; IFN-a: Interferon alpha; IL: Interleukin; IPSCs: Induced pluripotent stem cells; MLC: Megalencephalic leukoencephalopathy with subcortical cysts; MLD: Metachromatic leukodystrophies; MRI: Magnetic resonance imaging; MS: Multiple sclerosis; NVC: Neurovascular coupling; NVU: Neurovascular unit; OAPs: Orthogonal arrays of intramembranous particles; OOCs: Organs-on-chips; OPC: Oligodendrocyte progenitor cell; PLP1: Proteolipid protein 1; PMD: Pelizaeus-Merzbacher disease; PNS: Peripheral nervous system; RFs: Rosenthal fibres; ROS: Reactive oxygen species; SMA: Smooth muscle actin; SVZ: Subventricular zone; TJ: Tight junction; UPR: Unfolded protein response; WM: White matter; ZO-1: Zona occludens 1.

\section{Authors' contributions}

PZ, HNP, EMH, MB and HEdV designed the setup of the review. PZ and HNP wrote the manuscript, EMH, MB and HedV edited the text. HNP made the illustration. All authors agreed with the content of the manuscript. All authors read and approved the final manuscript.

\section{Funding}

PZ and MB are funded by the ZonMW Veni Grant \#016.196.107. HNP, EMH and HEdV are funded by the NWO HMM2.0 CONNECT Grant \#18957.

Availability of data and materials

Not applicable.

\section{Declarations}

Ethics approval and consent to participate

Not applicable.

\section{Consent for publication}

Not applicable.

\section{Competing interests}

The authors declare that they have no competing interests.

\section{Author details}

${ }^{1}$ Department of Pathology, Amsterdam Neuroscience, Amsterdam UMC, Vrije Universiteit Amsterdam, de Boelelaan 1117, Amsterdam, The Netherlands.

${ }^{2}$ Amsterdam Leukodystrophy Center, Amsterdam UMC, Amsterdam, The Netherlands. ${ }^{3}$ Department of Molecular Cell Biology and Immunology, Amsterdam Neuroscience, Amsterdam UMC, Vrije Universiteit Amsterdam, De Boelelaan 1117, Amsterdam, The Netherlands. ${ }^{4}$ Department of Translational Neuroscience, University Medical Center Utrecht Brain Center, Utrecht University, Utrecht, The Netherlands.

Received: 22 December 2021 Accepted: 11 February 2022

Published online: 28 February 2022

\section{References}

1. Attwell D, Buchan AM, Charpak S, Lauritzen M, MacVicar BA, Newman EA. Glial and neuronal control of brain blood flow. Nature. 2010;468:232-43.

2. Liebner S, Dijkhuizen RM, Reiss Y, Plate KH, Agalliu D, Constantin G. Functional morphology of the blood-brain barrier in health and disease. Acta Neuropathol. 2018;135:311-36. https://doi.org/10.1007/ s00401-018-1815-1.

3. Ransohoff RM, Engelhardt B. The anatomical and cellular basis of immune surveillance in the central nervous system. Nat Rev Immunol. 2012;12:623-35. https://doi.org/10.1038/nri3265.

4. Engelhardt B, Sorokin L. The blood-brain and the blood-cerebrospinal fluid barriers: function and dysfunction. Semin Immunopathol. 2009:31:497-511. 
5. Engelhardt B, Ransohoff RM. Capture, crawl, cross: the T cell code to breach the blood-brain barriers. Trends Immunol. 2012;33:579-89. https://doi.org/10.1016/j.it.2012.07.004.

6. Mahringer A, Fricker G. ABC transporters at the blood-brain barrier. Expert Opin Drug Metab Toxicol. 2016;12(5):499-508.

7. Miller DS. Regulation of $A B C$ transporters blood-brain barrier: the good the bad, and the ugly. Adv Cancer Res. 2015;125:43-70.

8. Carrano A, Snkhchyan H, Kooij G, van der Pol S, van Horssen J, Veerhuis $\mathrm{R}$, et al. ATP-binding cassette transporters P-glycoprotein and breast cancer related protein are reduced in capillary cerebral amyloid angiopathy. Neurobiol Aging. 2014;35:565-75. https://doi.org/10.1016/j. neurobiolaging.2013.09.015.

9. EIAli A, Hermann DM. ATP-binding cassette transporters and their roles in protecting the brain. Neuroscientist. 2011;17:423-36

10. De Bock M, Leybaert L, Giaume C. Connexin channels at the glio-vascular interface: gatekeepers of the brain. Neurochem Res. 2017:42:2519-36.

11. Hall CN, Reynell C, Gesslein B, Hamilton NB, Mishra A, Sutherland BA, et al. Capillary pericytes regulate cerebral blood flow in health and disease. Nature. 2014;508:55-60

12. Peppiatt CM, Howarth C, Mobbs P, Attwell D. Bidirectional control of CNS capillary diameter by pericytes. Nature. 2006:443:700-4.

13. Clarke LE, Barres BA. Emerging roles of astrocytes in neural circuit development. Nat Rev Neurosci. 2013;14:311-21.

14. Khakh BS, Sofroniew MV. Diversity of astrocyte functions and phenotypes in neural circuits. Nat Neurosci. 2017;18:942-52

15. Sofroniew MV, Vinters HV. Astrocytes: biology and pathology. Acta Neuropathol. 2010;119:7-35.

16. MacAulay N, Zeuthen T. Water transport between CNS compartments: contributions of aquaporins and cotransporters. Neuroscience. 2010;168:941-56. https://doi.org/10.1016/j.neuroscience.2009.09.016.

17. King LS, Kozono D, Agre P. From structure to disease: the evolving tale of aquaporin biology. Nat Rev Mol Cell Biol. 2004;5:687-98.

18. Neely JD, Amiry-Moghaddam M, Ottersen OP, Froehner SC, Agre P. Adams ME. Syntrophin-dependent expression and localization of aquaporin-4 water channel protein. Proc Natl Acad Sci USA. 2001;98:14108-13.

19. Noell S, Wolburg-Buchholz K, Mack AF, Beedle AM, Satz JS, Campbell $\mathrm{KP}$, et al. Evidence for a role of dystroglycan regulating the membrane architecture of astroglial endfeet. Eur J Neurosci. 2011:33:2179-86.

20. Lien CF, Mohanta SK, Frontczak-Baniewicz M, Swinny JD, Zablocka B, Górecki DC. Absence of glial a-dystrobrevin causes abnormalities of the blood-brain barrier and progressive brain edema. J Biol Chem. 2012;287:41374-85.

21. Dalloz C, Sarig R, Fort P, Yaffe D, Bordais A, Pannicke T, et al. Targeted inactivation of dystrophin gene product Dp71: phenotypic impact in mouse retina. Hum Mol Genet. 2003:12:1543-54.

22. Hoddevik EH, Rao SB, Zahl S, Boldt HB, Ottersen OP, Amiry-Moghaddam $M$. Organisation of extracellular matrix proteins laminin and agrin in pericapillary basal laminae in mouse brain. Brain Struct Funct. 2020;225:805-16. https://doi.org/10.1007/s00429-020-02036-3.

23. Nagelhus EA, Ottersen OP. Physiological roles of aquaporin-4 in brain. Physiol Rev. 2013;93:1543-62.

24. Abbott NJ, Rönnbäck L, Hansson E. Astrocyte-endothelial interactions at the blood-brain barrier. Nat Rev Neurosci. 2006;7:41-53.

25. Papadopoulos MC, Verkman AS. Aquaporin water channels in the nervous system. Nat Rev Neurosci. 2013;14:265-77.

26. Reed MJ, Damodarasamy M, Banks WA. The extracellular matrix of the blood-brain barrier: structural and functional roles in health, aging, and Alzheimer's disease. Tissue Barriers. 2019. https://doi.org/10.1080/21688 370.2019.1651157.

27. Prinz M, Jung S, Priller J. Microglia biology: one century of evolving concepts. Cell. 2019;179:292-311. https://doi.org/10.1016/j.cell.2019.08. 053.

28. Ginhoux F, Guilliams M. Tissue-resident macrophage ontogeny and homeostasis. Immunity. 2016:44:439-49. https://doi.org/10.1016/j. immuni.2016.02.024.

29. Rymo SF, Gerhardt H, Sand FW, Lang R, Uv A, Betsholtz C. A two-way communication between microglial cells and angiogenic sprouts regulates angiogenesis in aortic ring cultures. PLOS ONE. 2011;6(1): e15846.
30. Fantin A, Vieira JM, Gestri G, Denti L, Schwarz Q, Prykhozhij S, et al. Tissue macrophages act as cellular chaperones for vascular anastomosis downstream of VEGF-mediated endothelial tip cell induction. Blood. 2010;116:829-40.

31. Arnold T, Betsholtz C. Erratum: The importance of microglia in the development of the vasculature in the central nervous system. Vasc Cell. 2013;5(1):1-7.

32. Bugiani M, Plug BC, Man JHK, Breur M, Van Der KMS. Heterogeneity of white matter astrocytes in the human brain. Acta Neuropathol. 2021. https://doi.org/10.1007/s00401-021-02391-3.

33. Amor S, Mcnamara NB, Gerrits E, Marzin MC, Kooistra SM, Miron VE, et al. White matter microglia heterogeneity in the CNS. Acta Neuropathol. 2021. https://doi.org/10.1007/s00401-021-02389-x.

34. Wilhelm I, Nyúl-Tóth Á, Suciu M, Hermenean A, Krizbai IA. Heterogeneity of the blood-brain barrier. Tissue Barriers. 2016;4(1): e1143544.

35. Bernier LP, Brunner C, Cottarelli A, Balbi M. Location matters: navigating regional heterogeneity of the neurovascular unit. Front Cell Neurosci. 2021;15:1-14.

36. Villabona-Rueda A, Erice C, Pardo CA, Stins MF. The evolving concept of the blood brain barrier (BBB): from a single static barrier to a heterogeneous and dynamic relay center. Front Cell Neurosci. 2019;13:405.

37. Schaeffer S, ladecola C. Revisiting the neurovascular unit. Nat Neurosci. 2021;24:1198-209. https://doi.org/10.1038/s41593-021-00904-7.

38. Schlageter KE, Molnar P, Lapin GD, Groothuis DR. Microvessel organization and structure in experimental brain tumors: microvessel populations with distinctive structural and functional properties. Microvasc Res. 1999;58:312-28.

39. Filley CM, Fields RD. White matter and cognition: making the connection. J Neurophysiol. 2016;116:2093-104.

40. Zhang K, Sejnowski TJ. A universal scaling law between gray matter and white matter of cerebral cortex. Proc Natl Acad Sci. 2002;97:5621-6.

41. Kevelam SH, Steenweg ME, Srivastava S, Helman G, Naidu S, Schiffmann R, etal. Update on leukodystrophies: a historical perspective and adapted definition. Neuropediatrics. 2016;47:349-54.

42. Morell P,Wiesmann U. A correlative synopsis of the leukodystrophies. Neuropediatrics. 1984:15:62-5. https://doi.org/10.1055/s-2008-1052383.

43. van der Knaap MS, Valk J, de Neeling N, Nauta JJP. Pattern recognition in magnetic resonance imaging of white matter disorders inchildren and young adults. Neuroradiology. 1991;33:478-93.

44. van der Knaap MS, Bugiani M. Leukodystrophies: a proposed classification system based on pathological changes and pathogenetic mechanisms. Acta Neuropathol. 2017;134(3):351-82.

45. Zarekiani P, Breur M, Wolf NI, de Vries HE, van der Knaap MS, Bugiani M. Pathology of the neurovascular unit in leukodystrophies. Acta Neuropathol Commun. 2021;9:1-15. https://doi.org/10.1186/s40478-021-01206-6.

46. Pouwels PJW, Vanderver A, Bernard G, Wolf NI, Dreha-Kulczewksi SF, Deoni SCL, et al. Hypomyelinating leukodystrophies: translational research progress and prospects. Ann Neurol. 2014;76:5-19.

47. Charzewska A, Wierzba J, Iżycka-Świeszewska E, Bekiesińska-Figatowska M, Jurek M, Gintowt A, et al. Hypomyelinating leukodystrophiesa molecular insight into the white matter pathology. Clin Genet. 2016:90:293-304.

48. Koeppen AH, Ronca NA, Greenfield EA, Hans MB. Defective biosynthesis of proteolipid protein in Pelizaeus-Merzbacher disease. Ann Neurol. 1987;21:159-70

49. Southwood CM, Garbern J, Jiang W, Gow A. The unfolded protein response modulates disease severity in Pelizaeus-Merzbacher disease. Neuron. 2002:36:585-96.

50. Gow A, Sharma R. The unfolded protein response in protein aggregating diseases. NeuroMolecular Med. 2003;4:73-94.

51. Roboti P, Swanton E, High S. Differences in endoplasmic-reticulum quality control determine the cellular response to disease-associated mutants of proteolipid protein. J Cell Sci. 2009;122:3942-53.

52. Sima AAF, Pierson CR, Woltjer RL, Hobson GM, Golden JA, Kupsky WJ, et al. Neuronal loss in Pelizaeus-Merzbacher disease differs in various mutations of the proteolipid protein 1. Acta Neuropathal. 2009;1 18:1-7.

53. Wolburg H, Noell S, Fallier-Becker P, MacK AF, Wolburg-Buchholz K. The disturbed blood-brain barrier in human glioblastoma. Mol Aspects Med. 2012;33:579-89. https://doi.org/10.1016/j.mam.2012.02.003.

54. Warth A, Kröger S, Wolburg H. Redistribution of aquaporin-4 in human glioblastoma correlates with loss of agrin immunoreactivity from brain capillary basal laminae. Acta Neuropathol. 2004;107:311-8. 
55. Van Rappard DF, Boelens JJ, Wolf NI. Metachromatic leukodystrophy: disease spectrum and approaches for treatment. Best Pract Res Clin Endocrinol Metab. 2015;29:261-73. https://doi.org/10.1016/j.beem. 2014.10.001.

56. Polten A, Fluharty AL, Fluharty CB, Kappler J, von Figura K, Gieselmann $\checkmark$. Molecular basis of different forms of metachromatic leukodystrophy. N Engl J Med. 1991;324:18-22.

57. Gieselmann V, Krägeloh-Mann I. Metachromatic leukodystrophy_an update. In: Brain imaging with MRI CT an image pattern approach. Cambridge: Cambridge University Press; 2010. p. 69-70.

58. Van Der Voorn JP, Pouwels PJW, Kamphorst W, Powers JM, Lammens M, Barkhof F, et al. Histopathologic correlates of radial stripes on MR images in lysosomal storage disorders. Am J Neuroradiol. 2005;26:442-6.

59. Ortiz GG, Pacheco-Moisés FP, Macías-Islas MÁ, Flores-Alvarado LJ, Mireles-Ramírez MA, González-Renovato ED, et al. Role of the bloodbrain barrier in multiple sclerosis. Arch Med Res. 2014;45:687-97.

60. van der Knaap MS, Bugiani M, Mendes MI, Riley LG, Smith DEC, Rudinger-Thirion J, et al. Biallelic variants in LARS2 and KARS cause deafness and (ovario)leukodystrophy. Neurology. 2019;92:1225-37.

61. Van der Knaap MS, Naidu S, Breiter SN, Blaser S, Stroink H, Springer S, et al. Alexander disease: diagnosis with MR imaging. Am J Neuroradiol. 2001;22:541-52

62. Messing A. Alexander disease. In: Handbook of clinical neurology. Amsterdam: Elsevier; 2018. p. 693-700.

63. Hol EM, Pekny M. Glial fibrillary acidic protein (GFAP) and the astrocyte intermediate filament system in diseases of the central nervous system. Curr Opin Cell Biol. 2015;32:121-30. https://doi.org/10.1016/j.ceb.2015. 02.004 .

64. Brenner M, Johnson AB, Boespflug-Tanguy O, Rodriguez D, Goldman JE, Messing A. Mutations in GFAP, encoding glial fibrillary acidic protein, are associated with Alexander disease. Nat Genet. 2002;27:117-20.

65. Sosunov AA, McKhann GM, Goldman JE. The origin of Rosenthal fibers and their contributions to astrocyte pathology in Alexander disease. Acta Neuropathol Commun. 2017:5:27.

66. Tang G, Xu Z, Goldman JE. Synergistic effects of the SAPK/JNK and the proteasome pathway on glial fibrillary acidic protein (GFAP) accumulation in Alexander disease. J Biol Chem. 2006:281:38634-43.

67. Tang G, Perng MD, Wilk S, Quinlan R, Goldman JE. Oligomers of mutant glial fibrillary acidic protein (GFAP) inhibit the proteasome system in alexander disease astrocytes, and the small heat shock protein aB-crystallin reverses the inhibition. J Biol Chem. 2010;285:10527-37.

68. Tang G, Yue Z, Talloczy Z, Goldman JE. Adaptive autophagy in Alexander disease-affected astrocytes. Autophagy. 2008;4:701-3.

69. Tang G, Yue Z, Talloczy Z, Hagemann T, Cho W, Messing A, et al. Autophagy induced by Alexander disease-mutant GFAP accumulation is regulated by p38/MAPK and mTOR signaling pathways. Hum Mol Genet. 2008;17:1540-55.

70. Russo LSJ, Aron A, Anderson PJ. Alexander's disease: a report and reappraisal. Neurology. 1976;26:607-14.

71. Olabarria M, Putilina M, Riemer EC, Goldman JE. Astrocyte pathology in Alexander disease causes a marked inflammatory environment. Acta Neuropathol. 2015;130:469-86.

72. Goebel HH, Bode G, Caesar R, Kohlschuetter A. Bulbar palsy with Rosenthal fiber formation in the medulla of a 15-year-old girl. Localized form of Alexander's disease? Neuropediatrics. 1981;12:382-91.

73. Towfighi J, Young R, Sassani J, Ramer J, Horoupian DS. Alexander's disease: further light-, and electron-microscopic observations. Acta Neuropathol. 1983;61:36-42.

74. Crow YJ, Chase DS, Schmidt JL, Szynkiewicz M, Forte GM, Gornall HL, et al. Characterization of human disease phenotypes associated with mutations in TREX1, RNASEH2A, RNASEH2B, RNASEH2C, SAMHD1, ADAR, and IFIH1. Am J Med Genet A. 2015;167:296-312.

75. Sase S, Takanohashi A, Vanderver A, Almad A. Astrocytes, an active player in Aicardi-Goutières syndrome. Brain Pathol. 2018;28:399-407.

76. van Heteren JT, Rozenberg F, Aronica E, Troost D, Lebon P, Kuijpers TW. Astrocytes produce interferon-alpha and CXCL10, but not IL-6 or CXCL8, in Aicardi-Goutières syndrome. Glia. 2008;56:568-78.

77. Cuadrado E, Jansen MH, Anink J, De Filippis L, Vescovi AL, Watts C, et al. Chronic exposure of astrocytes to interferon-a reveals molecular changes related to Aicardi-Goutières syndrome. Brain. 2013;136:245-58.
78. Campbell IL, Krucker T, Steffensen S, Akwa Y, Powell HC, Lane T, et al. Structural and functional neuropathology in transgenic mice with CNS expression of IFN-a. Brain Res. 1999:835:46-61.

79. Akwa Y, Hassett DE, Eloranta M-L, Sandberg K, Masliah E, Powell H, et al. Transgenic expression of IFN-a in the central nervous system of mice protects against lethal neurotropic viral infection but induces inflammation and neurodegeneration. J Immunol. 1998;161:5016-26.

80. Han S, Lin YC, Wu T, Salgado AD, Mexhitaj I, Wuest SC, et al. Comprehensive immunophenotyping of cerebrospinal fluid cells in patients with neuroimmunological diseases. J Immunol. 2014;192:2551-63.

81. Klok MD, Bakels HS, Postma NL, van Spaendonk RML, van der Knaap MS, Bugiani M. Interferon-a and the calcifying microangiopathy in AicardiGoutières syndrome. Ann Clin Transl Neurol. 2015;2:774-9.

82. López-HernándezT, Ridder MC, Montolio M, Capdevila-Nortes X, Polder E, Sirisi S, et al. Mutant GlialCAM causes megalencephalic leukoencephalopathy with subcortical cysts, benign familial macrocephaly, and macrocephaly with retardation and autism. Am J Hum Genet. 2011;88:422-32.

83. Leegwater PAJ, Yuan BQ, van der Steen J, Mulders J, Könst AAM, Boor PKI, et al. Mutations of MLC1 (KIAA0027), encoding a putative membrane protein, cause megalencephalic leukoencephalopathy with subcortical cysts. Am J Hum Genet. 2001;68:831-8.

84. Harbord MG, Harden A, Harding B, Brett EM, Baraitser M. Megalencephaly with dysmyelination, spasticity, ataxia, seizures and distinc tive neurophysiological findings in two siblings. Neuropediatrics. 1990;21:164-8.

85. Miles L, DeGrauw TJ, Dinopoulos A, Cecil KM, Van Der Knaap MS, Bove KE. Megalencephalic leukoencephalopathy with subcortical cysts: a third confirmed case with literature review. Pediatr Dev Pathol. 2009;12:180-6.

86. Van Der Knaap MS, Barth PG, Vrensen GFJM, Valk J. Histopathology of an infantile-onset spongiform leukoencephalopathy with a discrepantly mild clinical course. Acta Neuropathol. 1996;92:206-12.

87. Duarri A, Teijido O, López-HernándezT, Scheper GC, Barriere H, Boor I, et al. Molecular pathogenesis of megalencephalic leukoencephalopathy with subcortical cysts: mutations in MLC1 cause folding defects. Hum Mol Genet. 2008;17:3728-39.

88. Ilja Boor PK, de Groot K, Waisfisz Q, Kamphorst W, Oudejans CBM, Powers JM, et al. MLC1: a novel protein in distal astroglial processes. J Neuropathol Exp Neurol. 2005;64:412-9.

89. Schmitt A, Gofferje V, Weber M, Meyer J, Mössner R, Lesch KP. The brainspecific protein MLC1 implicated in megalencephalic leukoencephalopathy with subcortical cysts is expressed in glial cells in the murine brain. Glia. 2003:44:283-95.

90. Teijido O, Martínez A, Pusch M, Zorzano A, Soriano E, del Río JA, et al. Localization and functional analyses of the MLC1 protein involved in megalencephalic leukoencephalopathy with subcortical cysts. Hum Mol Genet. 2004;13:2581-94.

91. Dubey M, Bugiani M, Ridder MC, Postma NL, Brouwers E, Polder E, et al. Mice with megalencephalic leukoencephalopathy with cysts: a developmental angle. Ann Neurol. 2015;77:114-31.

92. Favre-Kontula L, Rolland A, Bernasconi L, Karmirantzou M, Power C, Antonsson B, et al. GlialCAM, an immunoglobulin-like cell adhesion molecule is expressed in glial cells of the central nervous system. Glia. 2008;56:633-45.

93. Brignone MS, Lanciotti A, Serafini B, Mallozzi C, Sbriccoli M, Veroni C, et al. Megalencephalic leukoencephalopathy with subcortical cysts protein-1 (MLC1) counteracts astrocyte activation in response to inflammatory signals. Mol Neurobiol. 2019;56:8237-54.

94. Oosterhof N, Kuil LE, van der Linde HC, Burm SM, Berdowski W, van ljcken WFJ, et al. Colony-stimulating factor 1 receptor (CSF1R) regulates microglia density and distribution, but not microglia differentiation in vivo. Cell Rep. 2018;24:1203-1217.e6. https://doi.org/10.1016/j.celrep. 2018.06.113.

95. Stabile C, Taglia I, Battisti C, Bianchi S, Federico A. Hereditary diffuse leukoencephalopathy with axonal spheroids (HDLS): update on molecular genetics. Neurol Sci. 2016;37:1565-9.

96. Delaney C, Farrell M, Doherty CP, Brennan K, O'Keeffe E, Greene C, et al. Attenuated CSF-1R signalling drives cerebrovascular pathology. EMBO Mol Med. 2020;13(2): e12889. 
97. Baba Y, Ghetti B, Baker MC, Uitti RJ, Hutton ML, Yamaguchi K, et al. Hereditary diffuse leukoencephalopathy with spheroids: clinical, pathologic and genetic studies of a new kindred. Acta Neuropathol. 2006;111:300-11.

98. Sundal C, Jönsson L, Ljungberg M, Zhong J, Tian W, Zhu T, et al. Different stages of white matter changes in the original HDLS family revealed by advanced MRI techniques. J Neuroimaging. 2014;24:444-52.

99. Marotti JD, Tobias S, Fratkin JD, Powers JM, Rhodes CH. Adult onset leukodystrophy with neuroaxonal spheroids and pigmented glia: report of a family, historical perspective, and review of the literature. Acta Neuropathol. 2004;107:481-8.

100. Pixley FJ, Stanley ER. CSF-1 regulation of the wandering macrophage: complexity in action. Trends Cell Biol. 2004;14:628-38.

101. Easley-Neal C, Foreman O, Sharma N, Zarrin AA, Weimer RM. CSF1R ligands IL-34 and CSF1 are differentially required for microglia development and maintenance in white and gray matter brain regions. Front Immunol. 2019. https://doi.org/10.3389/fimmu.2019.02199.

102. Jin S, Sonobe $Y$, Kawanokuchi J, Horiuchi $H$, Cheng $Y$, Wang $Y$, et al. Interleukin-34 restores blood-brain barrier integrity by upregulating tight junction proteins in endothelial cells. PLoS ONE. 2014:9:1-11.

103. Yin D. Biochemical basis of lipofuscin, ceroid, and age pigment-like fluorophores. Free Radic Biol Med. 1996;21:871-88.

104. Halliwell B, Gutteridge JMC. Oxygen toxicity, oxygen radicals, transition metals and disease. Biochem J. 1984;219:1-14.

105. Ward RJ, Zucca FA, Duyn JH, Crichton RR, Zecca L. The role of iron in brain ageing and neurodegenerative disorders. Lancet Neurol. 2017:176:139-48.

106. Craggs LJL, Yamamoto Y, Deramecourt V, Kalaria RN. Microvascular pathology and morphometrics of sporadic and hereditary small vessel diseases of the brain. Brain Pathol. 2014;24:495-509.

107. Bosetti F, Galis ZS, Bynoe MS, Charette M, Cipolla MJ, Del Zoppo GJ, et al. "Small blood vessels: big health problems?": scientific recommendations of the national institutes of health workshop. J Am Heart Assoc. 2016:5:1-12.

108. Østergaard L, Engedal TS, Moreton F, Hansen MB, Wardlaw JM, Dalkara T, et al. Cerebral small vessel disease: capillary pathways to stroke and cognitive decline. J Cereb Blood Flow Metab. 2016;36:302-25.

109. Joutel A, Corpechot C, Ducros A, Vahedit K, Chabriatt H, Mouton P, et al. Notch3 mutations in CADASIL, a hereditary adult-onset condition causing stroke and dementia. Nature. 1996;383:707-10.

110. Ables JL, Breunig JJ, Eisch AJ, Rakic P. Not(ch) just development: Notch signalling in the adult brain. Nat Rev Neurosci. 2011;12:269-83.

111. Artavanis-Tsakonas S, Rand MD, Lake RJ. Notch signaling: cell fate control and signal integration in development. Science (80-). 1999;284:770-6.

112. Shawber CJ, Kitajewski J. Notch function in the vasculature: insights from zebrafish, mouse and man. BioEssays. 2004;26:225-34.

113. Irvin DK, Zurcher SD, Nguyen T, Weinmaster G, Kornblum HI. Expression patterns of Notch1, Notch2, and Notch3 suggest multiple functional roles for the Notch-DSL signaling system during brain development. J Comp Neurol. 2001:436:167-81.

114. Villa N, Walker L, Lindsell CE, Gasson J, Iruela-Arispe ML, Weinmaster G. Vascular expression of Notch pathway receptors and ligands is restricted to arterial vessels. Mech Dev. 2001;108:161-4

115. Lesnik Oberstein SAJ, van den Boom R, Buchem MA, van Houwelingen HC, Bakker E, Vollebregt E, et al. Cerebral microbleeds in CADASIL. Neurology. 2001;006:1066-70.

116. Liem MK, Lesnik Oberstein SAJ, Haan J, Boom RVD, Ferrari MD, Buchem MAV, et al. Cerebrovascular reactivity is a main determinant of white matter hyperintensity progression in CADASIL. Am J Neuroradiol. 2009;30:1244-7

117. Huneau C, Houot M, Joutel A, Béranger B, Giroux C, Benali H, et al. Altered dynamics of neurovascular coupling in CADASIL. Ann Clin Transl Neurol. 2018:5:788-802.

118. Hase Y, Chen A, Bates LL, Craggs LJL, Yamamoto Y, Gemmell E, et al. Severe white matter astrocytopathy in CADASIL. Brain Pathol. 2018;28:832-43.

119. Schoemaker D, Arboleda-Velasquez JF. Notch3 signaling and aggregation as targets for the treatment of CADASIL and other NOTCH3-associated small-vessel diseases. Am J Pathol. 2021;191:1856-70. https://doi. org/10.1016/j.ajpath.2021.03.015.
120. Belin De Chantemèle EJ, Retailleau K, Pinaud F, Vessières E, Bocquet $A$, Guihot AL, et al. Notch3 is a major regulator of vascular tone in cerebral and tail resistance arteries. Arterioscler Thromb Vasc Biol. 2008;28:2216-24.

121. Tikka S, Baumann M, Siitonen M, Pasanen P, Pöyhönen M, Myllykangas L, et al. CADASIL and CARASIL. Brain Pathol. 2014;24:525-44.

122. Timur ZK, Demir SA, Seyrantepe V. Lysosomal Cathepsin A plays a significant role in the processing of endogenous bioactive peptides. Front Mol Biosci. 2016:3:1-7.

123. Hiraiwa M. Cathepsin A/protective protein: an unusual lysosomal multifunctional protein. Cell Mol Life Sci. 1999;56:894-907.

124. Jackman HL, Massad MG, Sekosan M, Tan F, Brovkovych V, Marcic BM, et al. Angiotensin 1-9 and 1-7 release in human heart role of cathepsin A. Hypertension. 2002;39:976-81.

125. Bugiani M, Kevelam SH, Bakels HS, Waisfisz Q, Ceuterick-De Groote C, Niessen HWM, et al. Cathepsin A-related arteriopathy with strokes and leukoencephalopathy (CARASAL). Neurology. 2016;87:1777-86.

126. Smyth LCD, Rustenhoven J, Scotter EL, Schweder P, Faull RLM, Park TIH, et al. Markers for human brain pericytes and smooth muscle cells. J Chem Neuroanat. 2018;92:48-60. https://doi.org/10.1016/j.jchemneu. 2018.06.001.

127. Lendahl U, Nilsson P, Betsholtz C. Emerging links between cerebrovascular and neurodegenerative diseases - a special role for pericytes. EMBO Rep. 2019;20:1-18.

128. Alarcon-Martinez L, Yilmaz-Ozcan S, Yemisci M, Schallek J, Kılıç K, Can A, et al. Capillary pericytes express a-smooth muscle actin, which requires prevention of filamentous-actin depolymerization for detection. Elife. 2018:7:1-17.

129. Attwell D, Mishra A, Hall CN, O'Farrell FM, Dalkara T. What is a pericyte? J Cereb Blood Flow Metab. 2016:36:451-5.

130. Vuurmans TJL, Boer P, Koomans HA. Effects of endothelin-1 and endothelin-1 receptor blockade on cardiac output, aortic pressure, and pulse wave velocity in humans. Hypertension. 2003;41:1253-8.

131. Hammond TR, Gadea A, Dupree J, Kerninon C, Nait-Oumesmar B, Aguirre A, et al. Astrocyte-derived endothelin-1 inhibits remyelination through notch activation. Neuron. 2014;81:588-602. https://doi.org/10.1016/j.neuron.2013. 11.015 .

132. Adams KL, Riparini G, Banerjee P, Breur M, Bugiani M, Gallo V. Endothelin-1 signaling maintains glial progenitor proliferation in the postnatal subventricular zone. Nat Commun. 2020;11:1-17. https://doi.org/10.1038/ s41467-020-16028-8.

133. Onos KD, Rizzo SJS, Howell GR, Sasnera M. Toward more predictive genetic mouse models of Alzheimer's disease. Brain Res Bull. 2016:122:1-11.

134. Dawson TM, Ko HS, Dawson VL. Genetic animal models of Parkinson's disease. Neuron. 2010;66:646-61.

135. Ransohoff RM. Animal models of multiple sclerosis: the good, the bad and the bottom line. Nat Neurosci. 2012;15:1074-7.

136. Syvanen $\mathrm{S}$, Lindhe $\mathrm{O}$, Palner M, Kornum BR, Rahman O, Langstrom B, et al. Species differences in blood-brain barrier transport of three positron emission tomography radioligands with emphasis on P-glycoprotein transport. Drug Metab Dispos. 2009;37:635-43.

137. Lui JH, Nowakowski TJ, Pollen AA, Javaherian A, Kriegstein AR, Oldham MC. Radial glia require PDGFD-PDGFR beta signalling in human but not mouse neocortex Nature 2014:515:264-U258.

138. Zhang Y, Sloan SA, Clarke LE, Caneda C, Plaza CA, Blumenthal PD, et al. Purification and characterization of progenitor and mature human astrocytes reveals transcriptional and functional differences with mouse. Neuron. 2016;89:37-53.

139. Lui JH, Hansen DV, Kriegstein AR. Development and evolution of the human neocortex. Cell. 2011;146:18-36.

140. Sozmen EG, Kolekar A, Havton LA, Carmichael ST. A white matter stroke model in the mouse: axonal damage, progenitor responses and MRI correlates. J Neurosci Methods. 2009:180:261-72.

141. Brewer GJ, Espinosa J, Mcllhaney MP, PencekTP, Kesslak JP, Cotman C, et al. Culture and regeneration of human neurons after brain surgery. J Neurosci Methods. 2001;107:15-23.

142. Samarasekera N, Salman RA, Huitinga I, Klioueva N, McLean CA, Kretzschmar $\mathrm{H}$, et al. Brain banking for neurological disorders. Lancet Neurol. 2013;12:1096-105.

143. Myers TA, Nickerson CA, Kaushal D, Ott CM, Bentrup KHZ, Ramamurthy $\mathrm{R}$, et al. Closing the phenotypic gap between transformed neurona 
cell lines in culture and untransformed neurons. J Neurosci Methods. 2008;174:31-41.

144. Shastry P, Basu A, Rajadhyaksha MS. Neuroblastoma cell lines-a versatile in vztro model in neurobiology. Int J Neurosci. 2001;108:109-26. https://doi.org/10.3109/00207450108986509.

145. Horvath P, Aulner N, Bickle M, Davies AM, Del Nery E, Ebner D, et al. Screening out irrelevant cell-based models of disease. Nat Rev Drug Discov. 2016;15:751-69.

146. Bernas MJ, Cardoso FL, Daley SK, Weinand ME, Campos AR, Ferreira AJG et al. Establishment of primary cultures of human brain microvascular endothelial cells to provide an in vitro cellular model of the bloodbrain barrier. Nat Protoc. 2010;5:1265-72.

147. Stone NL, England TJ, O'Sullivan SE. A novel transwell blood brain barrier model using primary human cells. Front Cell Neurosci. 2019;13:230.

148. Hicks C, Stevanato L, Stroemer RP, Tang E, Richardson S, Sinden JD. In vivo and in vitro characterization of the angiogenic effect of CTXOE03 human neural stem cells. Cell Transpl. 2013;22:1541-52.

149. Gomez-Gaviro MV, Scott CE, Sesay AK, Matheu A, Booth S, Galichet $C$, et al. Betacellulin promotes cell proliferation in the neural stem cell niche and stimulates neurogenesis. Proc Natl Acad Sci USA. 2012;109:1317-22.

150. Bicker J, Alves G, Fortuna A, Falcao A. Blood-brain barrier models and their relevance for a successful development of CNS drug delivery systems: a review. Eur J Pharm Biopharm. 2014:87:409-32.

151. Lacar B, Herman P, Platel JC, Kubera C, Hyder F, Bordey A. Neural progenitor cells regulate capillary blood flow in the postnatal subventricular zone. J Neurosci. 2012;32:16435-21648.

152. Tan C, Lu NN, Wang CK, Chen DY, Sun NH, Lyu H, et al. Endotheliumderived semaphorin $3 \mathrm{G}$ regulates hippocampal synaptic structure and plasticity via neuropilin-2/plexinA4. Neuron. 2019;101:920.

153. Humpel C. Organotypic brain slice cultures: a review. Neuroscience. 2015;305:86-98

154. Duport S, Robert F, Muller D, Grau G, Parisi L, Stoppini L. An in vitro blood-brain barrier model: cocultures between endothelial cells and organotypic brain slice cultures. Proc Natl Acad Sci USA. 1998:95:1840-5.

155. Kovacs R, Papageorgiou I, Heinemann U. Slice cultures as a model to study neurovascular coupling and blood brain barrier in vitro. Cardiovasc Psychiatry Neurol. 2011;2011: 646958

156. Croft CL, Futch HS, Moore BD, Golde TE. Organotypic brain slice cultures to model neurodegenerative proteinopathies. Mol Neurodegener. 2019:14:45.

157. Takahashi K, Tanabe K, Ohnuki M, Narita M, Ichisaka T, Tomoda K, et al. Induction of pluripotent stem cells from adult human fibroblasts by defined factors. Cell. 2007;131:861-72.

158. Takahashi K, Yamanaka S. Induction of pluripotent stem cells from mouse embryonic and adult fibroblast cultures by defined factors. Cell. 2006;126:663-76.

159. Dolmetsch R, Geschwind DH. The human brain in a dish: the promise of iPSC-derived neurons. Cell. 2011;145:831-4.

160. Tyzack G, Lakatos A, Patani R. Human stem cell-derived astrocytes: specification and relevance for neurological disorders. Curr Stem Cell Rep. 2016:2:236-47.

161. Lam RS, Topfer FM, Wood PG, Busskamp V, Bamberg E. Functional maturation of human stem cell-derived neurons in long-term cultures. PLoS ONE. 2017;12: e0169506.

162. Neyrinck K, Van Den Daele J, Vervliet T, De Smedt J, Wierda K, Nijs M, et al. SOX9-induced generation of functional astrocytes supporting neuronal maturation in an all-human system. Stem Cell Rev Rep. 2021;17:1855-73. https://doi.org/10.1007/s12015-021-10179-x.

163. Kim K, Doi A, Wen B, Ng K, Zhao R, Cahan P, et al. Epigenetic memory in induced pluripotent stem cells. Nature. 2010;467:285-90.

164. Perrera V, Martello G. How does reprogramming to pluripotency affect genomic imprinting? Front Cell Dev Biol. 2019;7:76.

165. Noumbissi ME, Galasso B, Stins MF. Brain vascular heterogeneity: implications for disease pathogenesis and design of in vitro blood-brain barrier models. Fluids Barriers CNS. 2018;15:1-12. https://doi.org/10. 1186/s12987-018-0097-2.

166. Lancaster MA, Knoblich JA. Generation of cerebral organoids from human pluripotent stem cells. Nat Protoc. 2014;9:2329-40.
167. Ormel PR, Vieira de Sá R, van Bodegraven EJ, Karst H, Harschnitz O, Sneeboer MAM, et al. Microglia innately develop within cerebral organoids. Nat Commun. 2018;9:1-14. https://doi.org/10.1038/ s41467-018-06684-2.

168. Simian M, Bissell MJ. Organoids: a historical perspective of thinking in three dimensions. J Cell Biol. 2017;216:31-40.

169. Chukwurah E, Osmundsen A, Davis SW, Lizarraga SB. All together now: modeling the interaction of neural with non-neural systems using organoid models. Front Neurosci. 2019;13:582.

170. Antoni $D$, Burckel $H$, Josset $E$, Noel G. Three-dimensional cell culture: a breakthrough in vivo. Int J Mol Sci. 2015;16:5517-27.

171. Rothbauer M, Zirath $\mathrm{H}$, Ertl P. Recent advances in microfluidic technologies for cell-to-cell interaction studies. Lab Chip. 2018;18:249-70.

172. Bhatia SN, Ingber DE. Microfluidic organs-on-chips. Nat Biotechnol. 2014;32:760-72.

173. Halldorsson S, Lucumi E, Gomez-Sjoberg R, Fleming RMT. Advantages and challenges of microfluidic cell culture in polydimethylsiloxane devices. Biosens Bioelectron. 2015;63:218-31.

174. Dan P, Velot É, Decot V, Menu P. The role of mechanical stimuli in the vascular differentiation of mesenchymal stem cells. J Cell Sci. 2015;128:2415-22.

175. Zhang C, Zeng L, Emanueli C, Xu Q. Blood flow and stem cells in vascular disease. Cardiovasc Res. 2013;99:251-9. https://doi.org/10.1093/cvr/ cvt061.

176. Kadohama T, Nishimura K, Hoshino Y, Sasajima T, Sumpio BE. Effects of different types of fluid shear stress on endothelial cell proliferation and survival. J Cell Physiol. 2007;212:244-51. https://doi.org/10.1002/jcp. 21024.

177. Gao D, Liu H, Jiang Y, Lin J-M, Gao D, Liu H, et al. Recent developments in microfluidic devices for in vitro cell culture for cell-biology research. TrAC Trends Anal Chem. 2012:35:150-64.

178. Mestres G, Perez RA, D'Elía NL, Barbe L. Advantages of microfluidic systems for studying cell-biomaterial interactions-focus on bone regeneration applications. Biomed Phys Eng Express. 2019;5:32001. https://doi.org/10.1088/2057-1976/ab1033.

179. Gastfriend BD, Palecek SP, Shusta EV. Modeling the blood-brain barrier: beyond the endothelial cells. Curr Opin Biomed Eng. 2018;5:6-12.

180. Motallebnejad P, Thomas A, Swisher SL, Azarin SM. An isogenic hiPSCderived BBB-on-a-chip. Biomicrofluidics. 2019;13:64119.

181. Jamieson JJ, Linville RM, Ding YY, Gerecht S, Searson PC. Role of iPSCderived pericytes on barrier function of iPSC-derived brain microvascular endothelial cells in 2D and 3D. Fluids Barriers CNS. 2019:16:15.

182. Potjewyd G, Moxon S, Wang T, Domingos M, Hooper NM. Tissue engineering 3D neurovascular units: a biomaterials and bioprinting perspective. Trends Biotechnol. 2018;36:457-72.

183. Koivisto JT, Joki T, Parraga JE, Pääkkönen R, Ylä-Outinen L, Salonen $\mathrm{L}$, et al. Bioamine-crosslinked gellan gum hydrogel for neural tissue engineering. Biomed Mater. 2017;12:25014. https://doi.org/10.1088/ 1748-605X/aa62bo.

184. Bishop ES, Mostafa S, Pakvasa M, Luu HH, Lee MJ, Wolf JM, et al. 3-D bioprinting technologies in tissue engineering and regenerative medicine: current and future trends. Genes Dis. 2017:4:185-95.

185. Pham MT, Pollock KM, Rose MD, Cary WA, Stewart HR, Zhou P, et al. Generation of human vascularized brain organoids. NeuroReport. 2018;29:588-93.

186. Shi Y, Sun L, Wang M, Liu J, Zhong S, Li R, et al. Vascularized human cortical organoids (vOrganoids) model cortical development in vivo. PLoS Biol. 2020;18: e3000705.

187. Cakir B, Xiang YF, Tanaka Y, Kural MH, Parent M, Kang YJ, et al. Engineering of human brain organoids with a functional vascular-like system. Nat Methods. 2019;16:1169.

188. Salmon I, Grebenyuk S, Fattah ARA, Rustandi G, Pilkington T, Verfaillie C, et al. Engineering neurovascular organoids with 3D printed microfluidic chips. bioRxiv. 2021. https://doi.org/10.1101/2021.01.09.425975.

189. Wang Y, Wang L, Zhu Y, Qin J. Human brain organoid-on-a-chip to model prenatal nicotine exposure. Lab Chip. 2018;18:851-60.

190. Cho AN, Jin Y, An Y, Kim J, Choi YS, Lee JS, et al. Microfluidic device with brain extracellular matrix promotes structural and functional maturation of human brain organoids. Nat Commun. 2021;12:4730.

191. Eiraku M, Watanabe K, Matsuo-Takasaki M, Kawada M, Yonemura S, Matsumura M, et al. Self-organized formation of polarized cortical tissues 
from ESCs and its active manipulation by extrinsic signals. Cell Stem Cell. 2008;3:519-32

192. Qian X, Nguyen HN, Song MM, Hadiono C, Ogden SC, Hammack C, et al. Brain-region-specific organoids using mini-bioreactors for modeling ZIKV exposure. Cell. 2016;165:1238-54. https://doi.org/10.1016/j.cell. 2016.04.032.

193. Muguruma K, Nishiyama A, Kawakami H, Hashimoto K, Sasai Y. Selforganization of polarized cerebellar tissue in $3 \mathrm{D}$ culture of human pluripotent stem cells. Cell Rep. 2015;10:537-50.

194. Wolf NI, van Spaendonk RM, Hobson GM, Kamholz J. PLP1-related disorders. In: Adam MP, Ardinger HH, Pagon RA, Wallace SE, Bean LJH, Stephens KAA, editors. GeneReviews ${ }^{\circledR}$. Seattle: University of Washington; 1999.

195. Schiffmann R, van der Knaap MS. Invited Article: An MRI-based approach to the diagnosis of white matter disorders. Neurology. 2009;72:750-9.

196. Laukka JJ, Stanley JA, Garbern JY, Trepanier A, Hobson G, Lafleur T, et al. Neuroradiologic correlates of clinical disability and progression in the X-Linked leukodystrophy Pelizaeus-Merzbacher disease. J Neurol Sci. 2013;335:75-81.

197. Nezu A, Kimura S, Takeshita S, Osaka H, Kimura K, Inoue K. An MRI and MRS study of Pelizaeus-Merzbacher disease. Pediatr Neurol. 1998;18:334-7.

198. Seitelberger F. Neuropathology and genetics of Pelizaeus-Merzbacher disease. Brain Pathol. 1995;5:267-73.

199. Kumperscak HG, Plesnicar BK, Zalar B, Gradisnik P, Seruga T, Paschke E. Adult metachromatic leukodystrophy: a new mutation in the schizophrenia-like phenotype with early neurological signs. Psychiatr Genet. 2007;17:85-91.

200. Martin A, Sevin C, Lazarus C, Bellesme C, Aubourg P, Adamsbaum C. Toward a better understanding of brain lesions during metachromatic leukodystrophy evolution. Am J Neuroradiol. 2012;33:1731-9.

201. Singh RK, Leshner RT, Kadom N, Vanderver AL. Isolated cranial nerve enhancement in metachromatic leukodystrophy. Pediatr Neurol. 2009:40:380-2. https://doi.org/10.1016/j.pediatrneurol.2008.11.015.

202. Maia ACM, Da Rocha AJ, Da Silva CJ, Rosemberg S. Multiple cranial nerve enhancement: a new MR imaging finding in metachromatic leukodystrophy [1]. Am J Neuroradiol. 2007;28:999.

203. Prust M, Wang J, Morizono H, Messing A, Brenner M, Gordon E, et al. GFAP mutations, age at onset, and clinical subtypes in Alexander disease. Neurology. 2011;77:1287-94.

204. Rice G, Newman WG, Dean J, Patrick T, Parmar R, Flintoff K, et al. Heterozygous mutations in TREX1 cause familial chilblain lupus and dominant Aicardi-Goutières syndrome. Am J Hum Genet. 2007;80:811-5.

205. Livingston JH, Stivaros S, Van Der Knaap MS, Crow YJ. Recognizable phenotypes associated with intracranial calcification. Dev Med Child Neurol. 2013:55:46-57.

206. Tolmie JL, Shillito P, Hughes-Benzie R, Stephenson JBP. The AicardiGoutières syndrome (familial, early onset encephalopathy with calcifications of the basal ganglia and chronic cerebrospinal fluid lymphocytosis). J Med Genet. 1995;32:881-4.

207. Lebon P, Badoual J, Ponsot G, Goutières F, Hémeury-Cukier F, Aicardi $J$ I. Intrathecal synthesis of interferon-alpha in infants with progressive familial encephalopathy. J Neurol Sci. 1988;84:201-8.

208. Aicardi J, Goutieres F. A progressive Fdal encephalopathy in infancy with calcrfications of the basal Gangha and Chronic cerebrospinal fluid lymphocytosis. Ann Neurol. 1984;15:49-54.

209. van der Voorn JP, Pouwels PJW, Hart AAM, Serrarens J, Willemsen MAAP, Kremer $\mathrm{HPH}$, et al. Childhood white matter disorders: quantitative MR Imaging and spectroscopy. Radiology. 2006;241:510-7.

210. van der Knaap MS, Valk J, Barth PG, Smit LME, van Engelen BGM, Donati PT. Leukoencephalopathy with swelling in children and adolescents: MRI patterns and differential diagnosis. Neuroradiology. 1995:37:679-86

211. van der Knaap MS, Boor I, Estévez R. Megalencephalic leukoencephalopathy with subcortical cysts: chronic white matter oedema due to a defect in brain ion and water homoeostasis. Lancet Neurol. 2012;11:973-85. https://doi.org/10.1016/S1474-4422(12)70192-8.

212. Sundal C, Van Gerpen JA, Nicholson AM, Wider C, Shuster EA, Aasly J, et al. MRI characteristics and scoring in HDLS due to CSF1R gene mutations. Neurology. 2012;79:566-74.
213. van der Knaap MS, Naidu S, Kleinschmidt-DeMasters BK, Kamphorst W, Weinstein HC. Autosomal dominant diffuse leukoencephalopathy with neuroaxonal spheroids. Neurology. 2000;54:463.

214. Yamamoto Y, Craggs L, Baumann M, Kalimo H, Kalaria RN. Review: molecular genetics and pathology of hereditary small vessel diseases of the brain. Neuropathol Appl Neurobiol. 2011;37:94-113.

\section{Publisher's Note}

Springer Nature remains neutral with regard to jurisdictional claims in published maps and institutional affiliations.
Ready to submit your research? Choose BMC and benefit from:

- fast, convenient online submission

- thorough peer review by experienced researchers in your field

- rapid publication on acceptance

- support for research data, including large and complex data types

- gold Open Access which fosters wider collaboration and increased citations

- maximum visibility for your research: over $100 \mathrm{M}$ website views per year

At BMC, research is always in progress.

Learn more biomedcentral.com/submissions 